Florida International University FIU Digital Commons

FIU Electronic Theses and Dissertations

University Graduate School

6-18-1999

\title{
Children in science fiction utopias: feminism's blueprint for change
}

Jessica J. Brodie

Florida International University

DOI: $10.25148 /$ etd.FI14060895

Follow this and additional works at: https://digitalcommons.fiu.edu/etd

Part of the Children's and Young Adult Literature Commons, and the Feminist, Gender, and Sexuality Studies Commons

\section{Recommended Citation}

Brodie, Jessica J., "Children in science fiction utopias: feminism's blueprint for change" (1999). FIU Electronic Theses and Dissertations. 2425.

https://digitalcommons.fiu.edu/etd/2425

This work is brought to you for free and open access by the University Graduate School at FIU Digital Commons. It has been accepted for inclusion in FIU Electronic Theses and Dissertations by an authorized administrator of FIU Digital Commons. For more information, please contact dcc@fiu.edu. 
FLORIDA INTERNATIONAL UNIVERSITY

Miami, Florida

CHILDREN IN SCIENCE FICTION UTOPIAS:

FEMINISM'S BLUEPRINT FOR CHANGE

A thesis submitted in partial fulfillment of the

requirements for the degree of

MASTER OF ARTS

in

ENGLISH

by

Jessica Connor

1999 
To: Dean Arthur W. Herriott

College of Arts and Sciences

This thesis, written by Jessica Connor, and entitled Children in Science Fiction Utopias: Feminism's Blueprint for Change, having been approved in respect to style and intellectual content, is referred to you for judgment.

We have read this thesis and recommend that it be approved.

Lisa Blansett

Marilyn Hoder-Salmon

Charles Elkins, Major Professor

Date of Defense: June 18, 1999

The thesis of Jessica Connor is approved.

Dean Arthur W. Herriott College of Arts and Sciences

Dean Richard L. Campbell Division of Graduate Studies

Florida International University, 1999 
(C) Copyright 1999 by Jessica Connor All rights reserved. 


\section{DEDICATION}

I dedicate this thesis to my husband, John. His constant love, strength and reassurance have been a source of pure inspiration to me. Without his support, encouragement and unending patience, this thesis - and this writer - would not have been possible. A special thank you also goes out to my mother, Kathleen, and my sister, Sara, for providing the backbone for my utopian insights and the confidence to pursue my dreams. 


\section{ACKNOWLEDGMENTS}

I wish to thank the members of my committee for their wisdom, cooperation, efficiency and direction. I am truly grateful for the support and the encouragement of Dr. Lisa Blansett and Dr. Marilyn Hoder-Salmon, whose guidance has led me to a stronger vision, both feminist and utopian. And I am completely indebted to the reassurance, creative spirit and vast bookshelf of Dr. Charles Elkins, whose appreciation for the possibilities of social change in all types of literature cemented my belief that writing does indeed help to make the world a better place.

I have sincerely enjoyed the English Department's Graduate Program. The course subjects did not merely deal with the traditional literary canon but also encompassed a wide variety of contemporary, ethnic and feminist literature suitable for South Florida's environment. As well, the professors' quiet passion for their subjects was a true inspiration to me, guiding me toward a university career of my own.

Finally, I thank the authors of feminist science fiction utopias. Their courage to interpret this "brave new world" and guide society into a more peaceful and creative feminist future is to be applauded. 


\title{
ABSTRACT OF THE THESIS
}

\section{CHILDREN IN SCIENCE FICTION UTOPIAS:}

FEMINISM'S BLUEPRINT FOR CHANGE

\author{
by \\ Jessica Connor \\ Florida International University, 1999 \\ Miami, Florida \\ Professor Charles Elkins, Major Professor
}

The purpose of this thesis was to examine the treatment and portrayal of children in science fiction utopian literature and determine whether this effectively indicated the writers' feminist visions for social change. A feminist theoretical perspective and critical interpretation of several of the genre's canon, Sheri Tepper's The Gate to Women's Country, Suzy McKee Charnas's Motherlines, Sally Miller Gearhart's The Wanderground, Ursula Le Guin's The Dispossessed and Octavia Butler's Xenogenesis series, were used as research methodologies.

The findings revealed that children communicate feminist prescriptions for change in three ways: children as the literal, biological future, the link between two opposing societies, or the explanation for the difficult philosophies and structural elements of the societies. As this subject has been an unexplored area of criticism, it is recommended that critics begin to examine this treatment of children to more easily understand the writers' social visions and effect their blueprints for change. 


\section{TABLE OF CONTENTS}

CHAPTER

PAGE

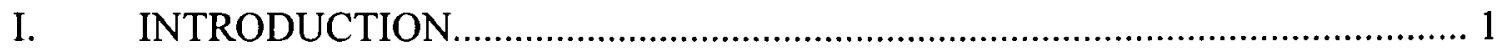

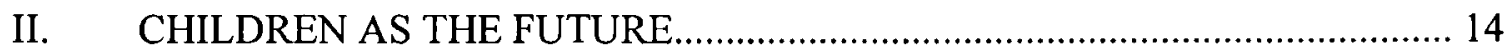

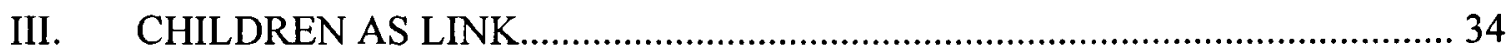

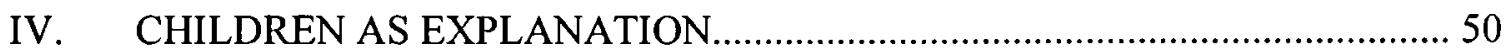

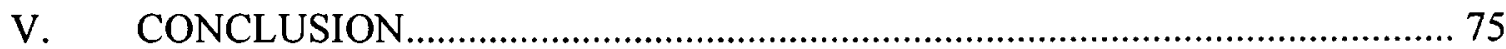

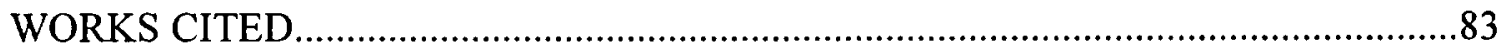




\section{INTRODUCTION}

One could argue that since realism by definition is grounded in the actual, patriarchal world, only $S F$, with its embrace of fantasizing and the impossible, can fully sustain a feminist vision of the future. (Roberts 137)

Writers who actively work toward achieving some sort of social reform, regardless of the vision, often turn to imaginative or futuristic realms in order to address the issues effectively, whether it is because what they are advocating is so radical that it must be masked by the fantastic in order to be free from censure, or because the authors cannot conceive of an actual present-day society fulfilling the vision they advance.

Science fiction utopian literature has therefore become an ideal vehicle for writers to further feminism. As Patrick Murphy states, "Feminist authors for centuries, and even more so today, have found the fantastic to be a mode of writing that enables them to inscribe the forbidden, to express the suppressed, to provide a voice for the silenced" (89). And as Joanna Russ maintains, "Utopias are not embodiments of universal human values, but are reactive; that is, they supply in fiction what their authors believe society...and/or women, lack in the here-and-now. The positive values stressed in the stories can reveal to us what, in the authors' eyes, is wrong with our own society" (81). In this thesis I will be addressing the treatment and portrayal of children in science fiction utopian literature and how they effectively indicate the authors' feminist visions for social change.

According to Kenneth Burke in The Philosophy of Literary Form, there is a societal tendency "to consider literature, not as a creator's device for self-expression, nor as an audience's device for amusement or instruction, but as a communicative 
relationship between writer and audience, with both parties actively participating" (329). And further, says Burke, literature is a strategic response to society: "One seeks to 'direct the larger movements and operations' in one's campaign of living. One 'maneuvers,' and the maneuvering is an 'art'" (298). This notion of literature as strategic communication allows for a logical correlation between literature and society: society spawns the issues, which generate the literature, which in turn helps to change society by exposing, as Peter Fitting says, "what we are actually struggling for" and proclaiming "that we still do have the possibility of constructing a future of our own choosing" ("For Men Only" 101).

But to effectively develop such a strategic literary communication, states Burke, one must "be realistic. One must size things up properly. One cannot accurately know how things will be, what is promising and what is menacing, unless he accurately knows how things are" (298). This, he indicates, can help "take literature out of its separate bin and give it a place in a general 'sociological' picture" (296) -- it can fuel social change. And American literary history has demonstrated this connection: Harriet Beecher Stowe's Uncle Tom's Cabin is probably the most illuminating example. Written in serial form in response to her strong anti-slavery vision, it sold 500,000 copies when published in book form in 1852 and is said to have played a key role in bringing about the Civil War ("Stowe"). In 1962, Rachel Carson's Silent Spring, which detailed the dangerous use of pesticides, led to a ban on DDT and the creation of the Environmental Protection Agency and the Clean Air and Clean Water Acts (DiSilvestro). Upton Sinclair's The Jungle, a criticism of the meatpacking industry, led to the 1906 Meat Inspection Act (Reed). Edward Bellamy wrote Looking Backward out of a desire to spread socialistic 
egalitarianism, which spawned "Bellamy Clubs" across the country trying to bring the author's socialistic utopian ideals into reality. And, says Burke, even Hitler's "Battle" (Mein Kampf) became a tool for the unification of his people (202-4).

Science fiction utopian writing is ideal ground for such social change, as well as for feminist theory. After all, says Anne Mellor, "Feminist theory is inherently utopian. Feminist theory is grounded on the assumption of gender equality, a social equality between the sexes which has never existed in the historical past" (243). Feminist literary theory allows for both a criticism of the male-dominated literary canon and a means to enlarge that canon to include works by those traditionally overlooked by patriarchal society: women. Further, as women have historically had no voice in the mainstream patriarchal canon, they have been left without a connection with the works or have been forced to identify with masculine visions over their own feminist visions. Although consciousness has been raised and the canon has been enlarged to include the works of many formerly slighted female writers, there are still more to be added and still more feminist issues to be dealt with within the literature ("Feminist Criticism").

As it is often difficult to ascertain exactly what the writer's feminist vision is in literature (as the protagonist or speaker is not necessarily representative of the writer), this thesis will show how an examination of children in science fiction utopian literature allows for a better and more objective way to understand the major themes and, hence, the writer's "blueprint" for feminism within her writings.

Sociologically, children are considered to be the future of society, both in biological, physical form and because they create the notion of a legacy. Vivian 
Sobchack, in her treatment on cultural meanings behind child narratives in horror and science fiction films, explains:

The secular baby and child have held a privileged place in bourgeois and patriarchal mythology since the nineteenth century. Infancy and childhood have subsequently been popularly represented as the cultural site of such "positive" virtues as innocence, transparency, and a "pure" and wonderful curiosity not yet informed by sexuality (no matter what Freud said).... Not yet having been subjected to the lessons of experience and history, the infant and child signify the subject of and experience and history still to be enacted and inscribed. In this way, the child becomes the signifier of the "future." (10-11)

Because of this, children are generally valued as a precious commodity and serve as a link to or between opposing forces. And because children are immature people, the treatment or portrayal of children is generally more simplistic and sympathetic. This notion of the importance of children and their signification of the future is echoed in Roger Neustadter's exploration of the role of children in critical theory:

Childhood is ideologically significant in critical theory. Critical theorists use childhood as a symbol of liberation and envision childhood as a means of change in elaborating their ideological position. On the one hand, an exaltation of childhood points to a critique of technological society. Childhood presents a new reality with an order of its own.... Critical theorists have found that the child's very autonomy gives it a transformative power which influences not only the image we have of children, but also the image of the future. (76)

This is little different from their treatment and portrayal by science fiction utopian writers. Critic Carol Pearson explores the domestic unit in feminist utopian fiction, particularly the mother/child bond, to show that these novels "do away with the division between the inhuman marketplace and the humane hearth" (64). She indicates that the mother/child, community/child family unit that is common to these utopias expresses the authors' desires for "families of equals, families which are not claustrophobic and 
nuclear. Rather, they are relatively large extended groups who freely choose to live together. The members of these groups are not divided into male and female roles" (67). This focus on children within the family unit can be taken further to concretely illustrate, in science fiction utopian authors' direct treatment and portrayal of children, the complex feminism behind the literature. This reading of several of the genre's canon, Sheri S. Tepper's The Gate to Women's Country, Suzy McKee Charnas's Motherlines, Sally Miller Gearhart's The Wanderground, Ursula K. Le Guin's The Dispossessed and Octavia E. Butler's Xenogenesis series - Dawn, Adulthood Rites and Imago, allows for the exploration of a logical, methodical study of the feminist "blueprint for change" in science fiction utopias, and it allows for the realization that through the treatment of children this feminist vision is more easily evident, understandable and likely to produce the changes the writers advocate.

It helps to understand a bit about science fiction in general and utopianism in particular to understand the significance of feminist science fiction utopias. Science fiction is characterized by some as "speculative fiction," i.e. by writers posing a hypothetical "what if" question as the basis for their writing and then attempting to answer that question within the text. Hence, in this sense, the "science" in science fiction does not necessarily mean fiction about science but rather fiction that poses such hypothetical questions as scientists would generally ask in their own research. And the "science" at hand does not necessarily need to be biological or natural science but social or other sciences as well. Mary Shelley's Frankenstein is said to be the mother of science fiction (Scholes and Rabkin 192), and it employs this speculative element along with its 
gothic elements.

And although a general understanding of utopia requires that it represent ultimate perfection, a sort of secular heaven where all humanity can achieve its ideal, most utopias are not representative of perfection but are usually just an alternate and imagined society that is "better" than the one out of which it was a response. Originally coined by Thomas More (Sargent xi), the word utopia in fact encompasses eutopia (an imaginary society much better than the author's society), dystopia (much worse than the author's society) and utopian satire (intended by the author to be a critique of contemporary society) (xii). A dystopia, by posing such an unbearable alternate society, can propel readers toward eutopian desires. Dystopia is, therefore, indirectly eutopian. But for simplicity's sake, the term utopia will be used here to comprise all the forms of utopianism as one.

With this in mind, the correlation between utopia and science fiction becomes much more evident. For the posing of imaginary societies naturally leads to the posing of scientific hypotheticals, which in turn becomes a great battleground for playing out feminist issues: what would happen if there were a world with only women? What would happen if men could give birth? The list is endless, and hence the opportunities this genre provides feminists is considerable.

In America as Utopia, Kenneth Roemer gives readers insight into the way utopianism has influenced America, a nation founded on freedom and political alternatives itself. This special link between utopias and America is thus illustrated:

American history is in part a history of potential dystopias and eutopias: the dystopian aura of the "howling wilderness," the genocide in the name of Manifest Destiny, the horrors of slavery, the nightmares of rampant commercialism, technology, urban squalor, Vietnam, Watergate and 
energy shortages; and the eutopian impulse of Winthrop's "Citty upon a Hill," Jefferson's Declaration of Independence, the possibilities for rebirth in the "virgin" West, the idealism of youth and civil rights movements, New Deals, New Frontiers, and Great Societies, and the technology and spirit that sent Americans to the moon and a bicentennial Viking to Utopia. To know America, we must have knowledge of America as utopia. (14)

Further, he states:

Utopian literature, along with the industrial novel, was part of a new use of fiction in America as a device for popularizing social and political ideas and for bringing about social change.... [It] perpetuated the American myth of political freedom by asserting that individuals could be free before they created the conditions through which their freedom could be realized. (131)

As we can see, this link between literature and society plays a significant role in social reform. According to Jean Pfaelzer, the women's suffrage movement of the 1910s and 1920s motivated Charlotte Perkins Gilman to create Herland and Moving the Mountain, and the equality movement of the 1960s and 1970s helped Joanna Russ to create The Female Man and Ursula Le Guin to create The Left Hand of Darkness and The Dispossessed (282). Feminist science fiction utopian literature is, hence, closely tied to our history. As Anne Mellor eloquently states, "Concrete utopian thinking is futurology: it offers a set of guidelines for social reform which might actually be utilizable. And these guidelines function both as a political program for immediate social change and as moral imperatives" (242). Subsequently, "Feminist utopian thinking...provides alternative models of sexually egalitarian societies and thereby defines the sources and directions of contemporary feminist desire. Insofar as feminist utopian thinking becomes concrete utopian thinking, it further offers potentially viable blue-prints for social organization. In these cases, feminist utopias both critique the present world and attempt 
to prophesy or determine the future" (243).

The 1960s and 1970s spawned the major feminist science fiction utopian movement (Fitting, "For Men Only" 101), most likely out of the women's issues fostered within the civil rights movement. Much of the feminist science fiction utopian canon originated during this time, as feminist issues were clearly at the center of public debate and thus quickened the amount of response-produced literature. But there are major differences between the literature produced during this movement and today's Millennium literature. The literature of the 1960 s and 1970s was absolutist, often extremist. It was radical new territory verging on a society begging for feminist direction. It needed to categorize men and women into opposite realms; it needed to create all-female worlds as an expression of the ideal society. It needed to portray men as weaklings, powerless fictionalizations trapped in the hands of powerful heroines. It needed to precisely and pragmatically blueprint the future in feminism, and its focus was almost entirely on patriarchal oppression. But, as Lucy Sargisson explains, "...few now claim to hold the universal solutions to patriarchal and perennial (universal) oppressions. Indeed, the concept of universal oppression has itself become suspect (64). Further, she adds, "There is less self-certainty and dogma in contemporary feminism than there was in that of, say, the 1970s, and more receptivity towards the validity of multiple readings and respect for diverse opinions. The multiplicity and openended nature of contemporary feminist utopianism are reflective of these concerns" (96).

Today's feminism seeks less to categorize than to explore. It enjoys the gray areas, rather than forcing issues into "blacks and whites." Readers see less of societies 
intended as precise models for the future and more of speculative examinations of what

things could be like in the future - not necessarily better, not necessarily worse. "Science fiction's new feminist chapter expresses a longing for a richer plurality of human images by portraying women as gendered or racial aliens who embrace, rather than quell, the invading monster" (Barr, Lost 99).

This notion of embracing the other, not fighting it, not running from it, but learning from and with it, is representative of the new Millennium's "openended" science fiction utopianism. As Phyllis Day says in "Earthmother/Witchmother: Feminism and Ecology Renewed," "There is little doubt that science fiction mirrors major trends in society" (12). In the 1960 s and 1970 s, women were fighting to make society aware of feminism, to force their way into the workplace and out of the homes. Today, society acknowledges feminism (even if many feminist battles still remain). Modern authors seek less to fight with their feminism than to simply make new gender roles a little easier to fit into.

Today's literature can afford to be racier than it was 30 years ago. Authors are now at much more ease to address "taboo" issues like bisexuality, menstruation, lesbianism, and inter-gender communication (Murphy 83). Hoda Zaki's lengthy description of what most modern feminist science fiction utopias contain is significant:

Small-sized communities that allow for much personal intercommunication; the basic unit is some form of the family or the extended family not built on biological kinship; the destruction of the nuclear family and the biological link between mother and child; a more egalitarian parent-child relationship; childcare to be a communal function; equal and sexually permissive relationships between the sexes (if both exist); no legal marriages; no taboos; no dualistic thinking; the elimination of cities and governments; the elimination of all hierarchies including 
class; decentralized decision-making processes; consensual decisions made in the interests of the common good; a redefinition of work to include pleasure, individual growth, and the common interest; and the elimination of a technology antagonistic to the environment. ("Utopia and Ideology" 121-2)

Renowned biologist Donna Haraway aligns contemporary science fiction utopian literature with the cyborg: "a cybernetic organism, a hybrid of machine and organism, a creature of social reality as well as a creature of fiction" (Simian 149). Like the science fiction utopian genre, the cyborg is a healthy sum of parts that does not fear its separateness, its disunity. "The cyborg is a creature in a post-gender world; it has no truck with bisexuality, pre-oedipal symbiosis, unalienated labor, or other seductions to organic wholeness through a final appropriation of all the powers of the parts into a higher unity" (150). This "organic wholeness" is the future of feminist science fiction utopianism.

Yes, the genre is changing, shifting into new roles, meeting not only new issues in feminism but new respect within the literary sphere as well. Lucie Armitt adamantly agrees: "For too long science fiction has been relegated lock, stock and barrel to the murky depths of that rather intangible, but often indiscriminately used term 'pulp fiction.' Finally, science fiction is taking the first steps towards overcoming the stigma which it has attracted in the eyes of the literary establishment, and not only has it become an item well and truly on the agenda at conferences, writers workshops and book fairs, but also in higher education establishments, where texts are increasingly included on the more progressive undergraduate syllabuses" (1).

But, say critics like Armitt, the genre is at the whim of the publishing industry 
which, with its marketing strategies and target audiences, wields considerable power over a book's reception, including how the book should be read and who should be reading it (Armitt 9). Because of this, and because critics like Barr feel that science fiction marginalizes the work that feminist writers produce, many believe that this literature should be taken entirely out of the science fiction genre and instead be labeled within a new field as feminist fabulation (Barr, Lost 98). "Male SF writers tell stories about men attempting to subdue natural phenomena; female SF writers tell stories about women attempting to subdue cultural phenomena.... 'Science' has little to do with the female SF writer's enterprise.... Members of the SF community should insist upon a new, appropriate and correct term to replace 'feminist SF'" (Barr, "Feminist Fabulation" 187).

The desire to change the science fiction label is understandable, of course, though perhaps not the best approach. But there still remains a strong need to increase scholarly awareness of the importance science fiction utopianism commands in terms of feminism. After all, says Sargisson:

Because they are explicitly imaginative, utopian theory and literature have been devalued in the schools of political theory and philosophy as escapist, fanciful and, above all, unscientific in disciplines which favour rational debate, logical argument and serious scholarship. It is, perhaps, ironic that within this undervalued genre the contribution of women writers should in turn be denied voice, as, for the main part, women writers of earlier centuries are rendered invisible by concentration on their male counterparts. It is also, perhaps, ironic that the words used to depreciate utopianism are those which Western binary thought designates 'feminine' as opposed to the rationality of masculine, 'scientific' debate. Its imaginative nature, its literary rather than explicitly theoretical form, contribute to what I later call utopia's cultural and social femininity. (412)

And, as mentioned, this "cultural and social femininity" is changing. Modern 
writers are embracing issues such as ecofeminism and bisexuality. And there is less emphasis on literature being a precise prescription for the future, though the impact these authors' "blueprints" have on society is astounding.

In fact, this notion of feminist science fiction utopianism serving as an author's blueprint for the future is cause for high debate within the field. One camp insists that the genre offers by nature a direct blueprint of the future, while the other attacks this notion as old-fashioned, stating that the new literature is too open-ended to offer any sort of concrete or universal model of the perfect society.

As critics like Anne Mellor maintain, "Those seeking a viable model of a nonsexist society must therefore look to the future; their model must be constructed first as a utopia, as a heuristic fiction" (243). This notion of the literature as a model for what the future should hold is echoed by Barr: "Feminist science fiction presents blueprints for social structures that allow women's words to counter patriarchal myths" (Lost 7).

But critics like Sargisson are adamantly against modern science fiction utopias serving as such blueprints. "Utopian thought is far more interesting and complex than is allowed by the standard view of utopia as a genre that represents a perfect society and offers a blue print for change," says Sargisson (39), firmly centered in the concept that the contemporary literature should reject such absolutist notions as a universal feminist vision. As she states:

The avoidance of the blueprint that is so common in contemporary feminist utopias can, I suggest, be connected to current debates within feminist theory centred upon the issue of essentialism.... The emergence of the open-ended feminist utopia is, I suggest, related to an unease within feminist theory with any ascription of a fixed nature to man and woman.... Wariness of the blueprint...can be found in the work of Margaret Whitford, 
whose work traverses all of these fields: 'Feminist philosophy is political and committed; it explicitly desires change, but to provide a blueprint in advance, explaining exactly what the nature of those changes will be, is to fall back into completely traditional methods of philosophy.' (Sargisson 51)

But whether these authors offer blueprints consciously or subconsciously, whether they prescribe blatant, all-encompassing visions or whether their utopian visions are buried deep within the text, whether they offer one blueprint or many, in one world or twenty worlds, these authors are still trying to deal with their present by offering readers their take on how our future could or should be. And no matter how recent or openminded a work is, it still inherently offers such a "strategic" vision as its nature. The literature may have shifted categories about what is taboo and what is common ground, but the role of the vision -- no matter what that vision is -- is still the same.

The treatment and portrayal of children in Tepper's The Gate to Women's Country, Charnas's Motherlines, Gearhart's The Wanderground, Le Guin's The Dispossessed and Butler's Xenogenesis series effectively indicate the authors' feminist visions. By examining children as the literal, biological future of the literature, the link between two opposing or utopian/dystopian societies, and the explanation for the difficult philosophies and structural elements of the societies, the authors' visions are easily recognized and serve as their feminist blueprint for change. 


\section{CHILDREN AS THE FUTURE}

Children embody the literal, biological future in many science fiction utopian works, helping readers to see a next breed of humanity and, hence, what the author's feminist vision is in concrete, physical reality. Sheri S. Tepper's The Gate to Women's Country, Suzy McKee Charnas's Motherlines, Sally Miller Gearhart's The Wanderground and Octavia E. Butler's Xenogenesis series (Dawn, Adulthood Rites and Imago) all illustrate this vision through their portrayal of children as the biological future of society.

Tepper's The Gate to Women's Country exhibits this theme through its selectively bred children. The novel takes place three hundred years after the earth was nearly destroyed by a nuclear holocaust, and the world has divided into two major societies divided by one gate: the violent, all-male warriors' garrisons, and Women's Country, where women and a few intelligent, nonviolent men peacefully coexist. Women's Country is entirely woman-oriented - the few males that live there are household servitors. Councilwomen handle the bureaucratic workings of the country and embody the society's peaceful feminist philosophy in their rituals. They are mostly doctors, and they facilitate a selective breeding program that is kept from nearly everyone in the society. Tepper appears to advocate the ends over the means in her portrayal of this program - for the sake of society, after all, selective breeding contributes to the creation of a better utopia by weeding out the undesirable element (violent men).

The Councilwomen, and many of the intelligent, feminist servitor men, believe that humans are potentially doomed because of the violence typically inherent in most 
men. (After all, it is men who started the wars and men who pushed the button, leaving behind a wasteland and only a handful of people in their wake.) But if society can breed this violent trait out of its people it has a better chance of surviving. As most women inherently exhibit the sort of intelligent, peaceful, cooperative behavior Women's Country advocates, the only men the Councilwomen select to serve as fathers are the servitors - kind, gentle men who have chosen to defy the biological odds that dictate they will remain with their gender to return back through the gate to Women's Country to live in the households of women. For these men are sent to live with the warriors when they are five, and those who choose to leave the men at 15 have thus exhibited their quality. And even these better caliber of men are further dissected as potential fathers: the Councilwomen particularly choose men who exhibit mental and artistic prowess, such as telepathy or clairvoyance, to father the children.

As the Council controls all breeding, this selection is achieved: sexual unions are only allowed twice per year at the carnival, and all women must visit a medical clinic to be vaccinated - and secretly implanted with contraception - before the carnival (71-2). Then at their after-carnival medical exam, the Council can then impregnate them if they choose to do so. Some women exhibit the irrational, selfish, violent behavior that is characteristic of the warriors, and they are sterilized to prevent them from populating Women's Country with anti-feminist children (179).

And the selective breeding program is working; already more males are returning through the gate and exhibiting mental powers like their fathers. Because of this, the new breed of children is increasingly more feminist, eco-minded, balanced, domestic and non- 
violent - exhibiting the author's feminist vision that only through such drastic measures as weeding out the negative violent traits from the gene pool will society fully reach its feminist dream and save itself from mass destruction.

The Councilwomen feel that the selection must be kept a secret from most women, at least for now, because many would not understand that the selection is necessary to preserve society. The warrior men are not told, as they would obviously resist their pending extinction. As Morgot, who is both on the Council and the chief medical officer for her town and who knows about the selection process, explains, "WWe put clues here and there, for those with the wits to see them. Most women don't know anything about it. We can't risk telling the ones who talk too much. Or the ones who drink a lot during carnival. Or those who are still young and silly. Who fall in love with warriors.... We medical officers work very hard, Stavia. It's all in our hands. Who bears, who doesn't. And when. And by whom. Haven't you noticed that almost all of the Council members are medically trained? Most of the women don't know what we're really doing. A very few figure it out for themselves"' (294).

Septemius, a peaceful traveling magician, is able to recognize these clues, and his confession to Morgot illustrates the lengths the Council must go through to conceal and carry out the selection as well as indicates the better male genes that are encouraged through selection:

"I am a magician. Magicians understand misdirection. We do it all the time. We say, watch my left hand, and then the right hand plays the trick. So it was easy for us to see the misdirection in what you were doing. You women were saying, "Watch us bringing sons to their warrior fathers, watch us weeping,' and all the time the trick was going on somewhere else... 
...There were other clues... Firstly, everyone said that more men came back through the gates in each succeeding generation. That argued for something, didn't it? Selection, perhaps?

...And then there's the matter of the servitors. Some of them, of course, are like Sylvia's Minsning, fluttery little fellows who are simply happier in Women's Country as cooks or tailors or what have you. For the most part, however, the servitors are more like Joshua or Corrig, highly competent, calm, judicious men, and they are highly respected, particularly by the most competent women. It argues both their status and their skills exceed what is generally supposed.

...They have martial skills, to be sure...but something other than that as well.... The old words for it were telepathy, clairvoyance." (287-9)

And as Morgot explains to her daughter Stavia, the novel's heroine, indicating Women's Country's focus on quality male traits, “'Joshua is your father, Stavvy. He's Habby and Byram and Jerby's father as well. And, of course, since there is only about one fertile servitor to every three fertile women, and since there's only one of Joshua's quality for every twenty, he's also fathered children for other women here in Marthatown and in other cities"' (293).

Stavia, Morgot's daughter, is caught between her emotions and the cold necessity of the selection when she is ultimately told the truth:

"We're selecting, aren't we?...And we'll keep doing it, on and on, and the years will go by, and eventually, all our sons will return home, is that it? No more penis worshipers? No more trumpets and drums and games? What will we do then, Morgot?"

"We won't have any more wars," Morgot said, holding her tightly. "Theoretically. No wars at all." (295)

These words capsulize the necessity of selectively breeding peaceful feminism into the future of Women's Country and breeding out the warriors.

Children also serve as the literal, biological future of the societies in Charnas's Motherlines. In the novel, Earth is divided up into three major societies after the nuclear 
Wasting destroyed the old system: 1) the violent, anti-feminist patriarchal society in the Holdfast, 2) the Riding Women of the plains, who were conceived in labs before the war and were genetically configured to breed without men, and 3) the free "fems," females who have escaped the Holdfast across the treacherous and barren desert and sought refuge in the Riding Women's plains.

The Riding Women comprise an all-female utopian society - they are cooperative and spiritual, and their entire world centers around the blood relation lines they call Motherlines. They work when they have to and do not plan for the future. They are fierce, and they value aggression and fighting as they live in the wild and it is required for their survival. They believe that sexuality is a healthy and joyful experience, and they do not exhibit jealousy. The Women are divided into more than a dozen camps across the plains region, and much of their work involves scouting - rescuing fems who have fled the Holdfast and killing any men who sought to conquer the plains. They embody Charnas's vision of the ideal feminist society.

The Riding Women are a society completely separate from men - thanks to some historical manipulations, their existence is a complete secret (73). They ride horses, an animal extinct in the Holdfast, and the men who witness their riding and flee back to the Holdfast do not believe they are people at all but monsters, a rumor which effectively prevents most men from trying to conquer the plains.

The free fems are just the opposite of the Riding Women. Like the Women only in their hatred of men, the fems are rescued by the Women but immediately turned out to camps of their own. The Women do not like the "slave mentality" of the fems, who have 
formed a violent, emotionless impersonal society identical to that of the Holdfast but without men - the women steal, cheat and lie to each other in a sort of cutthroat, selfish existence, just as they had done as captives in the Holdfast. Their only common goal is the desire to journey back to the Holdfast to rescue the other fems, but the Women prevent the fems from doing so because they fear it would jeopardize the Women's safe, isolated existence by taking away the men's idea that the Women are monsters.

In Motherlines, children serve to demonstrate the biological future of society in two major ways: through children formed through the Riding Women's self-breeding process and through Sorrel as the future of the merged fem/Woman society.

The Riding Women breed through the help of horses. As a pre-Wasting laboratory experiment to breed mind powers, the ancestors of these women were genetically reconfigured by lab workers to make seed with a double set of traits (74). They only need a certain "fluid" to initiate the self-breeding process, and their offspring are all daughters that look and act similar to their mothers. As Riding Woman Nenisi explains to Alldera, “' Our seed, when ripe, will start growing without merging with male seed because it already has its full load of traits from the mother. The lab men used a certain fluid to start this growth. So do we"' (74). The fluid these women use is from their intercourse with horses, and the new breed of children is all woman, not part horse, not part man.

The children formed are just like their mothers - they are not clones, but they look nearly identical (46), and they have the same sort of character and physical traits as their Motherline. For instance, Nenisi’s Conor line exhibits strong justice-giving traits, dark skin and problems with teeth (28), while other lines have sallow skin, red hair, high 
tempers or other distinguishing traits. As Alldera realizes as she watches them interact in the Group Tent one evening, "They were like some woven design in which each broad, clear thread could be traced in the image of each Motherline, repeated from individual to individual and from generation to generation" (67). And these children are the biological future of the Riding Women - until the arrival of Alldera introduces the possibility of a "femmish" Motherline.

The Women's horse mating is an elaborate ritual where they celebrate their own future in the conception. Young girls must carefully stretch themselves so that they are not injured by the large size of the horse (102), and the mating is performed in a bedding chute:

It was a rectangular box with three closed sides, an open top, and a high floor. The insides of the floor and walls were padded with leather cushions. Arched across the open top and joining the two long walls was a carefully padded super-structure to take the weight of the stallion and the grip of his forelegs. It would suspend his body over the young woman lying inside the box. There were ropes to release an escape trap for a woman whose mating went wrong and endangered her (173).

The entire group of women joins together once a year at the Gather for this joyous, ceremonial mating. First, the young women who wish to mate choose their stallion in a passionate, powerful horse dance in front of all the women (172-3). The next night, the women assemble around the bedding chute, singing their self-songs jubilantly with the excitement of the occasion (173-4). Then, one by one, the young women mate with their horses, as exemplified by one young girl's experience:

The moist wind stirred the hair of the young Hont candidate who stepped first into the open....

The youngster strolled the circumference of the dance ground, smiling, waving to women who called her name in the midst of their 
singing....

The Hont climbed into the chute and lay down on her back. One of her sharemothers got in with her to encourage and caress her so she would be moist and open to her stud....

Into the circle of onlookers came two of the Hont's family. The bay stallion stepped along neatly between them....

The handlers rubbed the neck and chest of the little stallion. They stroked his face and nostrils with pads that had been run under the tails of mares in season. He began to throw his head and snort, and within a few moments they had him erect. Under the touch of hands well known to him he reared high and clamped his forelegs on the padded support frame. He gripped the leather roll at the chute's head and rattled it with his teeth. Standing outside the chute, the handlers stroked his sweating neck and shoulders and bent to guide him.

Suddenly he thrust forward against the wooden braces which prevented him from entering fully. He oscillated his rump, snorting loudly, and his tail jerked, marking the rhythm of his ejaculation. Within seconds, it seemed, he pulled back and stood dark with sweat, droopheaded, quiet.

...Others of her family reached to help the young Hont up, but she was already on her feet in the chute. She swung her robe around herself with a grand gesture that showed as well as anything could her triumphant success. (174-6)

Because of the fluid these girls received from the horse mating, they were able to trigger the next breed of Riding Women and continue the survival of the society. And because they are able to perform reproduction without men, they are thus able to achieve Charnas's vision of an all-female utopia.

Sorrel, Alldera's daughter, is not of the Riding Woman breed. She is a child of Alldera, but she suckled these women, as did Alldera when she was unconscious and still pregnant with Sorrel, and because of this the women believe the girl is part Riding

Woman. She holds the promise that she can create a new Motherline, and though in this book she is too young to begin her mating ritual, many of the camp, including Nenisi, believe that she may be able to self-reproduce the way the Riding Women can. As she 
explains to Alldera, "'We don't have our forebears' wisdom or the wonders of the lab to change her to be like us, but we've tried to do it with what we have"' (75).

But more importantly, Sorrel serves as the future of both the femmish and Riding Women societies as, even though she has not yet proved her ability to self-reproduce, she is part Riding Woman because of the suckling and child rearing and hence she is kin to the Women. And because she is kin, she introduces a new breed of people into the Riding Women society: the free fems, who the Riding Women consider to be her distant kindred. The merged society is now the plains region's future, and the isolated lifestyle these women have been living is on the verge of change because of this. Already, this new "line" of fems is planning a return to the Holdfast to rescue their sisters, and for the first time the Women may not stop them. As Nenisi explains, “For generations women have watched so that no free fems would go back to the Holdfast and turn the men's attention toward the plains. That was right to do as long as we were few and the men were many, and as long as the free fems were strangers to whom we owed nothing. Now that relationship has changed. The free fems are kindred of the camps and free to go where they like..."' (271).

Because of the Motherline begun in Sorrel, and the kindred lines she has in the rest of the fems, the feminist future of the world is different, more encompassing, and the possibility of a new Motherline in Sorrel is strong, leading to a new breed of people in the future.

In Sally Miller Gearhart's The Wanderground, the unique earth-woman breed of the Hill Women's children serves to signify the eco-feminism of the culture as well as the 
safe, peaceful feminist vision that Gearhart suggests can only be found in a society without men.

After the violent, misogynistic Purges and Hunts the men of the City conducted years ago to rid their society of feminism and feminist women, the women who revolted and fled the City formed a new society of Hill Women based entirely on an earthbalanced philosophy. These women are in complete connection with the earth and all its open, earth-friendly creatures, from grass and trees to the river to animals to each other, and they have learned to cleanse themselves of the closed, patriarchal City mentality to adopt the natural communication the earth provides - psychic "mindspeak." By opening their minds to each other and to the earth, the Hill Women are able to return to their basic sensual roots in the earth and share thoughts and perceptions (2), as well as perform telepathic activities such as windriding, which involves using breathing to relax and achieve mind over matter to allow the wind to carry one's body (103-4), toting, which allows a woman to tap into the force of an object to cause it to move (108), and joining, which allows them to telepathically join with a body such as water or trees to absorb its essence and ensure their own survival when they are weak or lost (11).

These women are able to reproduce without men, as they have discovered how to mate with the earth to conceive their children. As Li warmly wishes Fora, who is about to conceive, "'I wish you well in the implantment, in the egg-merging, and in the bearing of new life"' (44), which effectively summarizes the process through which these women conceive. For their children are a perfect blend of woman and earth - one with the earth in all of its pure, open elements and in perfect harmony with true feminism - which 
signifies Gearhart's eco-feminist vision.

This mating with the earth is described in Fora's experience in the Kochlias. In the "Deep Cella" chapter, Fora visits the center, or deep cella, of the Kochlias to review the place as a potential mating site. As she surveys the site, she is overcome with a future vision, or forwardsense, of what her conception will be like, illustrating the vast process of the reproduction. Women conceive as a group of seven sisters - one "fleshmother" and six sisters. And Fora is able to clearly picture the ritual procession of the implantment: "A long line of women surging down the path, their arms and voices linked to each other, carrying with them the oils and the sweet scents, the fire, the water, the necessary green living plants. Beside them and before them, whatever small animals wished to come" (46). The women must journey to a warm, womb-like spot deep near the center of the earth, so imbedded that it is compared to the "tight end of the conch" (50). The earth at this proximity to its core produces a sharp gust of heat from a black gaping hole that allows a woman to be implanted and hence to reproduce. And Fora imagines this implantment rite in all its passionate connection:

She stepped aside and saw herself lying upon the floor of stone. Hot bodies surrounded her: Juda's head to her left at waist level, Tolatilita's to her right; Yva and Rhoda prone on each of her legs; Lyssa and Phtha hovering over her own head. They wiped her face, her body, with sharpsmelling leaves. The incantations swirled around and over her, words circling her head, her body, words sliding over her skin, drooping around her ribs and over her brow, under her fingernails and through the curling forest of the mountain slopes and planes... A thousand hands now moved on her flesh, a thousand eyes now peered at the window of her soul, a thousand lips caressed at the door of her deepest self. (51)

The children are part woman, part earth, and some children do not even look like their mothers, though they are all human. Seven year old Clana, for instance, has white 
skin though all of her mothers are dark, clearly indicating that she is not all woman but part of the mysteries of the earth as well (29).

And because of this merged species of human, they need a deep physical connection with the earth when they are upset or dying - when a woman "needs earth," the other women crowd around her and "lock in with her," chanting earth mantras over and over:

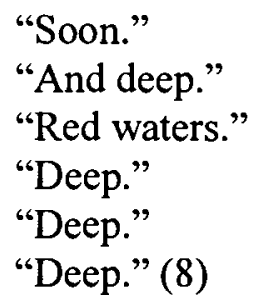

As Alaka explains when Ursula worriedly mindstretches to her about her momentary disappearance from the listenspread: "“Evona needed earth" (9). This need to connect with the earth symbolizes the Hill Women's part woman, part earth existence.

In Octavia Butler's Xenogenesis series, made up of Dawn, Adulthood Rites and Imago, she introduces an entirely new answer to gender and other problems in humans: the forfeiture of half our humanness to merge with alien life forms and create what she believes humans are biologically incapable of - a truly accepting feminist and non-racist society. Butler's views are subtle - she does not proselytize, but rather leaves the feminist and other philosophies to the reader to garner from her representations - but her brand of feminism is clearly advocated in her portrayal of the alien Oankali utopian society.

The series begins as nuclear war has all but destroyed earth, and space traveling, gene-trading aliens called the Oankali make the decision to merge with the dying humans 
in order to rescue them from their impending deaths from nuclear freeze and fallout - a self-imposed nuclear "suicide" they say the inherently flawed Human Contradiction drove humans to commit. (The Oankali say humans are fundamentally intelligent and hierarchical, and humans' intelligent exploitation of that hierarchy - the Human Contradiction - is what the Oankali believe drove them to destruction.)

Lilith is one of a handful of humans rescued from the earth who survived the initial destruction, and she awakens after a deep, non-aging sleep aboard the Oankali ship to find the earth almost healed and herself in the hands of completely alien creatures. It is precisely Lilith's easy acceptance of difference that leads the Oankali to choose her to be the "mother" of the other humans who will re-inhabit the world with the Oankali - and this acceptance is what readers will come to see is innate in most females, though it is not immediately apparent until Adulthood Rites. (Butler's males are usually stubborn and violent and clearly the most problematic of their species.) And it is to Lilith that Jdahya, an Oankali, explains the Human Contradiction in all human beings:

"You are intelligent," he said. "That's the newer of the two characteristics, and the one you might have put to work to save yourselves. You are potentially one of the most intelligent species we've found, though your focus is different from ours...."

"What's the second characteristic?"

"You are hierarchical. That's the older and more entrenched characteristic. We saw it in your closest animal relatives and in your most distant ones. It's a terrestrial characteristic. When human intelligence served it instead of guiding it, when human intelligence did not even acknowledge it as a problem, but took pride in it or did not notice it at all.... I think your people did not realize what a dangerous thing they were doing." (Dawn 37).

The Oankali are gene traders, and this is something they must perform as a part of their own genetic makeup - when they encounter a new species they must observe it, 
absorb it, and merge with it to become an entirely synergistic species. As Jdahya explains

to Lilith, ““We must do it. It renews us, enables us to survive as an evolving species instead of specializing ourselves into extinction or stagnation"" (39). And humans have no choice in the matter.

As part of this genetic engineering, the Oankali restore the dying earth over the course of hundreds of years and genetically reconfigure the humans so that they are free from cancer and other diseases - but they are now incapable of reproducing on their own. Now, humans must reproduce with the Oankali, and their children will be Oankali-human “constructs."

Oankali children are gender-free until they enter their metamorphosis, when a sex becomes apparent to them: male, female or ooloi. Males and females are nearly indistinguishable (Adulthood Rites 8), another indication of the feminist Oankali way, but the ooloi are what define the Oankali. Translated roughly to "bridge," "treasured

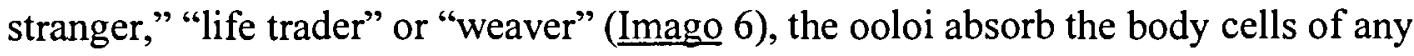
living creature through a special organelle (the Yashi) and can manipulate these cells to heal, begin reproduction, and indicate what the next generation will be like. The ooloi are the link between the Oankali and between the other species, and they ensure the future.

Imaginably, most humans resist this merging, indicating their inherent flaw. Back on earth, they flee and form their own childless societies, and they revert to Neanderthalesque gender relations where woman are possessions and violence is borne out of hopelessness. Some humans, however, remain with the Oankali because of the opportunity to bear children and ensure that some small part of them is carried on through 
time, and because of the draw of the peaceful, cooperative, feminist Oankali society. These humans embody Butler's feminist vision, for the Oankali society mirrors typical feminist utopias. The resister humans represent Butler's dystopian anti-feminist vision, particularly because they not only resist the feminist Oankali way but they wallow in violence and hierarchy.

Dawn details the humans' preparation to return to earth and the introduction of the idea of merging with the Oankali, Adulthood Rites examines the first human-born male construct, and Imago explores the first construct ooloi, with all creations serving as the future of humanity and the gene swapping Oankali.

In Dawn, Lilith, a 28 year old black woman, represents the best version of humanity, and she is chosen as the first human awakened from the long healing sleep to guide the other humans toward the Oankali way before their return to earth. Her sex, race and friendship with the Oankali cause Lilith's task to be an ultimate failure with the humans, a telling refection of Butler's feminist and other visions, but it is through Lilith that we are initially introduced to the future of these two peoples - children that will be a perfect mix of humans and Oankali. As Jdahya gently explains when she is first awakened:

"Your people will change. Your young will be more like us and ours more like you. Your hierarchical tendencies will be modified and if we learn to regenerate limbs and reshape our bodies, we'll share those abilities with you..."

...She spoke quickly, trying to blot out thoughts of more surgery or some sort of sex with the damned ooloi. "What will you make of us? What will our children be?"

"Different, as I said. Not quite like you. A little like us." (40)

Even the more-accepting, more-Oankali humans like Lilith still inherently resist 
the reality of the new species, but for survival's sake they acquiesce to the Oankali way. But as much as they try to accept the reality, they do not fully understand it - the Oankali believe at their core that the biology of the humans will lead to their destruction, and that only a deletion of the Human Contradiction in the new species will ensure their survival, even if it does mean the extinction of the full human species. They believe that to allow humans another chance would be cruel, as it would only be prolonging the eventual suicide. But they believe the merged Oankali-human constructs will understand, and accept, this reality because they will be without the Contradiction. As ooloi Kahguyaht coldly informs Lilith, “'Your children will know us, Lilith. You never will”" (111).

Humans are valuable to the Oankali because they foster certain physical gifts like cancer, which though deadly to humans is useful to the Oankali because it encourages limb regeneration and form changing. And the new breed will have both the humans' regeneration gifts and intelligence and the Oankali craving of difference and its sensory ability. The Oankali are able to read and duplicate genetic prints, something humans cannot do, but the constructs will be able to (127). Nikanj, the child ooloi who ultimately forges a link with Lilith beneficial to both societies, sums this up: “OUr children will be better than either of us...We will moderate your hierarchical problems and you will lessen our physical limitations. Our children won't destroy themselves in a war, and if they need to regrow a limb or to change themselves in some other way they'll be able to do it"" (247). But as Lilith says in response, “They won't be human"” (247).

Akin, a child of Lilith, shows us the reality of this future in book two of the series, Adulthood Rites. Akin is the first human-born male construct in the earth "construct 
society." He not only illuminates the future of society, but he is indicative of whether the Oankali have managed to put their theories into concrete practice.

Up until now, the Oankali were worried about allowing human women to give birth to male constructs because in order to survive they must have more of the Human Contradiction merged into them than any of the other human- or Oankali-born constructs (198). Human women gave birth to construct daughters, while Oankali women gave birth to construct sons. (By this admission, Butler subtly reveals her later theme that males are much of humanity's problem because they do in fact contain more of this Contradiction.)

Constructs are borne of five parents, all playing an equal role in the parenting process - a human mother, human father, Oankali mother, Oankali father and an ooloi to tie it all together. Human born constructs take eleven months to be born rather than their original nine, while Oankali boru constructs take fifteen months instead of the original eighteen (Adulthood Rites 83). And up until now, the oolois have been exactingly careful about influencing the gender of these children, though traditional Oankali society dictates that children are gender-free until metamorphosis. But Akin is the first male, and from the start, although he initially looks more human because he is borne of a human mother (all constructs change their appearance drastically at their later metamorphosis), he is clearly a merged child. The Oankali have a remarkable memory, and so Akin remembers much of his time in the womb (3). As he later honestly explains, "I don't forget things"” (104). He knows his name within his first few days of life (4) and can speak in simple sentences by the time he is two months old (5). Although he looks entirely human, his grey sensory tongue is the one physical trait that indicates his construct breed - with the 
tongue he tastes, or absorbs, cells to learn from everything in sight, from people to potentially dangerous plants in the area. As he later adamantly insists to resister humans who do not understand his ways, “I must put things in my mouth to understand them. Not to try would be like having hands and eyes always being tied and blindfolded. It would make me...not sane"" (161). Akin is also able, like most Oankali, to see through many other areas on his body than his eyes. In fact, his eyes are the least likely zone he would choose to look from, though Lilith encourages him to use them more when dealing with humans (15).

And as ooloi Nikanj predicts, his behavior will be dramatically different from the typical domestic-oriented Oankali and construct society so far: he will be a "solitary wanderer," and because he and his type are inherently non-monogamous (as most human males are said to be) he will change the traditional Oankali family unit: "A complete domestic family will be a female, an ooloi, and children. Males will come and go as they wish and as they find welcome" (10-11). As Nikanj explains, “"Trade means change. Bodies change. Ways of living must change. Did you think your children would only look different?"'(11).

Akin ultimately proves that construct society can still be successful and cooperative even with all the Human Contradiction in human-born males. But more questions about an uncertain future are raised when Lilith's later child, Jodahs, develops into the first ooloi construct.

Now that any male-female construct problems have been dealt with (in part thanks to Akin), the construct children have reverted to traditional Oankali gender roles. 
Although many children look or identify with male or female genders from a young age, they are still considered to be "eka": a child too young to have metamorphosed into its

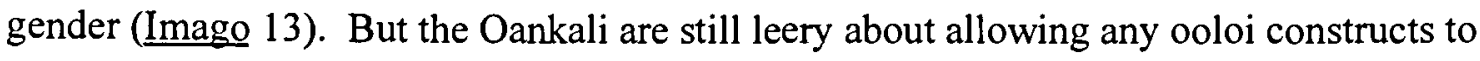
develop and, though still feminist, gender identities are firmly established so as not to accidentally breed ooloi constructs too soon. For although ooloi are integral to the functioning of the new merged species, up until now Oankali ooloi have been sent from the ship whenever new construct families are needed (15). But through the carelessness that too much relaxed familiarity breeds in Oankali ooloi (as what happens with Nikanj, Jodahs' ooloi parent), Jodahs has accidentally developed into this first construct ooloi, with dangerous consequences. For although at first examination Jodahs appears to be flawless, a flawed ooloi would be disastrous, endangering the survival of the entire species. As Jodahs shudders, it would be, "A flawed natural engineer - one who could distort or destroy with a touch. Nothing could save it from confinement on the ship. Perhaps it would even have to be physically altered to prevent it from functioning in any way as an ooloi. Perhaps it would be so dangerous that it would have to spend its existence in suspended animation, its body used by others for painless experimentation, its consciousness permanently shut off' (21). It could destroy the world.

Ooloi construct metamorphosis is much more subtle than male and female construct metamorphosis, with most of the changes taking place internally. Jodahs must completely relearn the fundamental cellular structure of everything it encounters: "River water, for instance: when I swam in it, I noticed that it had two distinctive major flavors hydrogen and oxygen? - and many minor flavors. I could separate out and savor each 
one individually. In fact, I couldn't help separating them" (3). Soon, it develops Yashi, the organelle that defines the ooloi and separates it from other genders. As Jodahs comes to realize, "We were what we were because of that organelle. It made us collectors and traders of life, always learning, always changing in every way but one - that one organelle. Ooloi said we were that organelle - that the original Oankali had evolved through that organelle's invasion, acquisition, duplication, and symbiosis" (23).

Jodahs is eventually able to change his form at whim or subconsciously; for instance, it becomes amphibian or reptile-like and grows webbed fingers and toes when squishing through the wet forest, losing its hair and turning from flesh colored to graygreen (69). It is still unconsciously problematic - although it can fix those problems, after a long spell of sleep or extended genetic absorption it alters the composition of the living structure Lo on which it lay (33). But in a short time it learns to locate and activate genes in Nikanj's arm (28), heal its own bullet wounds (52), alter the pelvis of a human female so that she can bear children (60), and regenerate the leg of a damaged human male (72). In short, Jodahs develops into a successful ooloi, offering readers a glimpse of the construct future and ensuring the survival of the feminist Oankali. 


\section{CHILDREN AS LINK}

In many science fiction utopian works, children serve as the link between warring or differing societies. This is apparent in Tepper's The Gate to Women's Country, Charnas's Motherlines and Butler's Xenogenesis series. By bridging two societies, children are able to illustrate the author's feminist vision by either allowing the link to create a better feminism or by identifying the preferable feminist society by countering it with a less-apparent dystopia.

In Tepper's The Gate to Women's Country, male children serve as a link between the warriors and Women's Country because they serve as an excuse for the men and women to come together in copulation (the societies are otherwise kept completely separate) and because they are shared between the two societies.

Although the Council selectively breeds undesirable male traits out of its children, and many of these children's "fathers" are actually not their fathers at all, this is largely unbeknownst to all the warriors and most of the women. And for these unknowing men and women, male children serve as their only bridge. (Girl children do not serve as a link between societies, as warriors consider females to be worthless except in providing their sons and do not consider girls to be their children.)

The two societies are kept entirely separate except for certain occasions: the onemonth long carnival season, where the warriors and women copulate and, most believe, procreate, the elaborate welcoming ceremony when a male child turns five and must be given to his warrior "father" (13-16), and the ritual ceremony when male children reject Women's Country or return through the gate. 
Women supposedly conceive the "warrior's sons" during carnival, and this is one way that children serve to bridge the two societies - they allow for healthy libidinal fulfillment and they supposedly allow them to procreate.

But we see the real link the children serve when the mothers must ceremoniously bring their children into the warrior's plaza to deliver their sons. The ceremony exchanged before the crowd between Morgot and the warrior Michael exhibits this:

"Warrior, I bring you your son," Morgot said, pushing Jerby a step or two in front of her.

... "I give him into your keeping until his fifteenth year," Morgot went on. "Except that he shall return to his home in Women's Country during the carnival holidays, twice each year until that time."

"A warrior chooses his way at fifteen." Michael was thundering once more....

"In that year he shall choose," said Morgot, stepping back and leaving Jerby there all alone.

The little boy started to turn, started to say, "Mommy," but Michael had seized him up, lifted him high, high above his head, high above his dark eyes and laughing mouth, high above his white gleaming teeth and cruelly curving lips as he cried, "Warriors! Behold my son!" (15)

This system works for both societies: the warriors fiercely value the camaraderie and fighting prowess of their fellow men and even pay homage to a sort of penis monument in their plaza (17). Hence, their children help populate this society and serve their male kinship. On the other hand, Women's Country is valuable and prosperous but entirely non-violent. Weapons are simply not allowed. But because the women serve the warriors' needs by giving them their male children, the warriors generally do not attack the towns and steal their food supplies and other commodities: "Women knew the warriors protected them only because women bore them sons," Chernon's narration voice tells readers. "In bearing a son for a warrior, a woman earns her life" (143). 
Also telling is the symbolism inherent in the gate that divides the societies. The gate is rich in maternal and sexual symbols, highlighting the only reasons these two worlds are connected: "Narrow and quite unpossessing.... a simple sheet of polished wood, with a bronze latch in the shape of a ghost of Iphigenia holding a child before the walls of Troy. On the right was a bronze latch in the shape of a pomegranate, set low, so that even a small woman could reach it easily... the door swung open smoothly, as though well used, well oiled" (5-6). Although the societies are entirely separate and do not even like each other, for the sake of the children they interact and remain peaceful.

Children, represented by Sorrel, also serve as a link between the differing peoples of Charnas's Motherlines: between the Riding Women and Alldera, and between the Riding Women and the free fems.

Alldera is neither free fem nor Riding Woman - although she escaped from the Holdfast, she is enveloped by the Riding Women because of her child and soon loses her slave mentality, which makes her different from the free fems. But she is not a Riding Woman, though she adopts much of their lifestyle. While she rides horses, learns to fight and appreciates the cooperative living, she does not contain the full set of genes the way the Women do and she does not mate with horses. As Alldera puzzles over what to name her daughter, the free fem Daya sums up Alldera's difficult position:

She tapped Daya's knee. "I've got to find a name! Not a name from the old life, like those you've suggested. Think of a name that's not property of the fems and not the property of the women either."

Daya smiled her scarred smile. "Call her 'Alldera."' (230)

The Riding Women do not make a practice of taking rescued escapees into their camps; rather, they turn them over almost immediately to the free fem camps. But 
because Alldera escaped from the Holdfast pregnant with her daughter, the child serves as a link between Alldera and the Riding Women, and ultimately she serves as a link between the Riding Women and the fems as well. For not only do the Women accept the child out of their respect for children, as Alldera thought for a time, but they accept the child because they believe by nursing and raising the child as one of their own they could possibly influence her to become more like the Riding Women's breed and create a new Motherline. As Nenisi explains to Alldera:

"When you came to us, that child was still forming inside you. We made you sleep to rest and strengthen you both. We fed you the milk of our breasts and the food chewed in our mouths, the food of Motherlines we feed our babies that. We fed your child, through your blood while she was still in your womb. We think she's become like our own children. We still feed her - that's why we do all her nursing. You see how healthily she grows, how fast, just like other babies here. We don't have our forebears' wisdom or the wonders of the lab to change her to be like us, but we've tried to do it with what we have." (75)

Because of this, the child serves as a link between Alldera and the Riding Women. As Nenisi puts it, "“You brought us a live child. Only one other fem did that, and that child we couldn't save. Your child is alive; that makes you kin to us"' (74).

But this summation meets opposition with some of the other women in the camp, represented by the harsh, aggressive Sheel. Sheel hates fems because of the slavery they represent, and she almost caused Alldera's death because she didn't check the food supply the Women kept in the desert for escaping fems. This is a serious though unintentional error on Sheel's part, and because she must pay for her mistake she resents Alldera and the unborn child even more (25-8). And, Sheel believes, the child is not even a full Riding Woman as she has no kin (29). 
The link Sorrel serves between Alldera and Sheel is important because Sheel is an outspoken voice for the Women, and her views can potentially break the greater link that forms simultaneously between Alldera and the rest of the Riding Women. Hence, to offset Sheel's hatred and to provide kin for the unborn child, Nenisi, the speaker for the camp, decides that the best way to entrench the child's position in the camp is for Sheel and the rest of the rescuing group to become her family. (There are no leaders among the Riding Women, but Nenisi's line exhibits strong justice-giving traits.) As Nenisi decrees:

"[The child]'ll have all the kin she needs...Alldera Holdfaster the fem will be bloodmother to her. Barvaran will be one of her sharemothers, to offset negligence of duty on patrol; and Shayeen, who was too sick to be blamed but who was there; and I myself, as spokeswoman for the judgment; and you too, Sheel, so that you can pay for your ill will and the deaths that it almost caused. We'll all be her family, which is an honor; the child from the Holdfast may grow up to found a new Motherline among the camps of the plains." (29)

Sheel resents this all the more, but she must live with it, and this forced link lessens the wrath of her hatred over time. Once, after Sheel is particularly disgusted at having to interact with Alldera at the child's coming out ceremony, her heartmother convinces her to take part in the ceremony by stating: "Except for you, Sheel, there would be no Holdfaster Tent. You cared for that baby, you nursed it, just as the other sharemothers did. That child will look for you in Holdfaster Tent, and she won't find you in Nenisi or Shayeen or Barvaran or Alldera and her femmish friend. You are the only Sheel Torrinor there is. The child has a claim on your mothering right to the end of her childhood, whatever her background may be, whoever her other mothers are"” (200). Because of this link, no matter how forced it is, Sorrel continues to forge a bond between Sheel and Alldera. And later Sheel comes to like the child, which fulfills much of the 
link's purpose. As she states when Sorrel wants to risk her life to prove her reputation, "'Sorrel has no blood relations to keep her line among us. If she has no children of her own body, after her death she'll just - disappear.... I don't want Sorrel to be lost at all"” (261). For aggressive, belligerent, fem-hating Sheel, speaking these words is an admission of her ultimate acceptance.

The child rearing in Holdfaster Tent also serves to fuel the link between Alldera and the Riding Women. Alldera and the four Women share a tent (40), nurse the child (all Riding Women have the ability to nurse at whim) (41-2), and fully participate in the mothering. The child is no longer Alldera's own - it is the tent's. The child now has five mothers, and she is part femmish, part Woman. And because of Sorrel, Alldera can remain at the camp. She has status. She is kin, as Nenisi says. And even when Alldera retreats from the Riding Women to live with the free fems for a time (repelled by the Women's mating with horses), she is still connected to her "people": a rider from the women must still keep her informed when the child enters the pack (127-8) and when she is ready to come out of the pack (181). And Alldera later breathes a sigh of relief when she recognizes a relation to one of her fellow sharemothers, Shayeen, in strangers after she knocks a Riding Woman from her horse, for she knows that the Motherline of Shayeen will ensure that she is treated properly (189).

During Sorrel's coming out ceremony, more links form over the child between Alldera and the Women. Alldera and the Women take part in the ceremony together, and the rituals are not altered in any way because of Sorrel's mixed heritage (227). And Alldera approves of the ceremony, which demonstrates her acceptance of the Riding 
Women's way (220). She and the Women of Holdfaster Tent share in the ritual over the child, all taking part in the ritual hair washing that serves as a child's first acquiescence to the way of the Riding Women over the childpack (222). And though Alldera is her "bloodmother," Sorrel chooses Barvaran as her "heartmother," indicative of the true link she serves to forge between Alldera and the Riding Women (220-1).

Because Alldera is a fem, but not necessarily a free fem, she does leave the Women to live with the free fems at one point. She is shocked by the barbarism and patriarchal mentality these former slaves have maintained, and she makes an enemy of herself of nearly everyone at the camp, almost succeeding in getting herself killed in the process. Eventually, she returns to the Riding Women for Sorrel's coming out, bringing the free fem Daya with her. Because Daya has gained many enemies in the free fem camps, her time with the Women is a refuge for her, and she is welcome at Stone Dancing Camp because she calls herself a cousin of Alldera. Soon, other free fems who disagree with the hostile slavish way of the free fem camps follow Daya to the Women, also calling themselves "cousins" - the Women consider all fems to be distant cousins of each other (235) - and ultimately adopting the open ways of the Riding Women.

Not only do the Women look down on the fems because they do not rise up and fight against the men, instead fleeing like cowards, but they also do not forge bonds with the fems because they do not share Motherlines. As Nenisi explains to Alldera when Alldera asks why the fems were not taken into the camp as she was: "You have a child here; kindred. The free fems are not related to anyone"" (71).

But because of an interest in Alldera's child, the fems make camp on the outskirts 
of Stone Dancing Camp and fuse themselves with the Women over the child. For instance, at Sorrel's coming out, it is customary for the Women to give presents to the child, but the fems also bring Sorrel gifts (228). And when the fems protest the coming out ceremony, which they are not supposed to attend, Alldera allows their femmish song to take her song's place in the ritual singing of the other sharemothers, symbolizing the fusing of the two groups in Sorrel (233). And after the coming out, instead of returning to the free fems camps, these fems choose to remain and learn from the Women. As Alldera realizes, "They came for the child and now they mean to stay and have me teach them to ride and shoot and track" (236). These fems give up the brutal way of their own camp to embrace the benefits of the Women, their former enemies, something they would never before have done had they not been lured to Stone Dancing Camp because of the child.

And because of this link, the free fems begin to change: "The quarreling and lying and stealing were giving way to other things: pride in new skills, ambition, some kind of group spirit" (244). And their eagerness to master the skills they learned turn them into "useful allies" for the Women, satisfying both peoples (245). And most importantly, the effects of the link work their way into Sheel as well: "Even Sheel, unwilling as she was, had to admit that the longer they lived here in the camp the more their slavish ways fell away from them. Everyone noticed that they all quarreled and intrigued far less among themselves than when they had been only a handful" (264). And the fulfillment of Charnas's vision of the merging of the two societies into one balanced feminist society is summarized in Sheel's words as well:

The thing Sheel had always feared - that the free fems would truly determine to return to the Holdfast, with unforeseeable consequences for 
all women - was clearly happening. As a nightmare, the imagination had maddened her. Now...it became simply a fact of the future to be dealt with in its time. (267)

And Sorrel, the link, likes both fems and Women equally, summing up the spirit of the two merged societies within her in her conversation with Sheel:

"Why don't you like the fems?" Sorrel had spent more time with them since the sharu swarming.

"Why do you like them?"

"Oh..." Sorrel made a ludicrously long and dreamy face. "I think they're very strong and sad because of their terrible lives."

"They're from the Holdfast," Sheel said. "I don't like things from the Holdfast."

"Am I from the Holdfast too?"

"You're one of us."

"I am a little Holdfastish in my blood, and special." (258)

In Butler's Xenogenesis series, children are used as links in various ways: In

Dawn, Nikanj as child ooloi helps fuse an easier link between the Oankali and Lilith. In

Adulthood Rites, Akin as a child construct serves as a link between the resisters and the

Oankali by offering an insight into a new planet for resister humans to populate and breed on, and he also embodies the greater link between the Oankali and humans. In Imago, Jodahs as child ooloi serves as a link between resister humans and the Oankali way, as well as serving as the greater link between humans and the Oankali in both its ooloi and construct status. Again, Butler's utopian portrayal of the Oankali equates an acceptance of the Oankali with feminism and a rejection of the Oankali with anti-feminism.

Child ooloi Nikanj serves as the bridge between Lilith and the Oankali in Dawn. Because it is a child, it is much more sympathetic to Lilith, who as a human threatened with extinction is highly resistant to the merged species the Oankali propose. Because it is a child just learning to use its individual ooloi gifts, and because the two are paired 
together in near isolated learning and develop a strong relationship, Nikanj helps make the Oankali way and the notion of a merged species much easier for her to accept.

The premise for the paired relationship between the child ooloi and Lilith is twofold: she will teach it about humans and it will teach her about the Oankali (Dawn 53). The two can barely speak the same language, but they must learn together as children (54). Because it is a child, and because it is Nikanj, it is much less repellent and cold than the other ooloi, who Lilith feels treat her like a species to be dissected. For instance, when she finds Nikanj had lay down beside her in her bed, "Her first impulse was to push the child away in revulsion or get up herself. Her second, which she followed, wearily indifferent, was to go back to sleep" (57).

Lilith quickly overcomes her revulsion for Nikanj, in part because it is smaller and less "ooloi" as it has not yet metamorphosed, in part because it knows her as a person and not as something merely to be studied. And later, she admits to Jdahya that she prefers Nikanj over him, even though Jdahya was her initial Oankali contact: "Nikanj was appealing - probably because it was a child. It was no more responsible for the thing that was to happen to the remnants of humanity than she was. It was simply doing - or trying to do - what the adults around it said should be done. Fellow victim? No, not a victim. Just a child, appealing in spite of itself. And she liked it in spite of herself' (70). Her acceptance of Nikanj transfers to a near acceptance of the overall Oankali way by the end of book one, which is a metaphor for her acceptance of the feminist, humanistic society Butler advocates.

In Adulthood Rites, not only does Akin (as a child construct) embody the physical 
link between the Oankali and humans as he is the merged breed of both, but he also serves as a link between the resister humans and the Oankali.

Although many humans set up camp with the Oankali and accept the Oankali way, partly because they want children, partly because of the utopian Oankali society, many humans resist this lifestyle and flee the Oankali construct villages. These resisters form towns loosely based on the "old way," and they revert to traditional sexist gender roles based on hierarchy: men tend to be violent and Neanderthalian, focusing on possession and aggression, and their women are merely objects, kept in the house, stolen or traded as goods and raped. At best, they are a man's wife. The resisters sink into despair when they realize the Oankali have not lied to them, that they have been genetically altered so they cannot breed without the ooloi. Their violence increases with this realization. They desperately want children, and their hopelessness destroys them by the day.

Akin is stolen by resisters when he is an infant and sold to Phoenix, the wealthiest resister trading village. He is initially kidnapped because he looks so human, and later he is accepted because of his human looks and because he is a child and hence more likeable. Because he is part of their society most of the Phoenix resisters start to warm to him. For instance, his childish presence seemed to "delight" the people of Phoenix, and they enjoy having him sit on their laps and telling him stories (120). And even his adultlike speaking voice and intelligence do not repulse resister strangers: a female salvager looks shocked and then grins as the human-looking toddler answers her question seriously (140). As he states, “"Humans like me...I guess because I look like them"” (15). Because Akin is a construct, he has elements of both peoples within him and can 
understand the mentality of the resisters. But because he was kidnapped by them and forced to live with them, he serves as a true link in a greater capacity - he introduces hope and a future for these resisters. He vehemently fights for the resisters' sake to create a new colony on Mars to send those humans who do not wish to merge with the Oankali. As he exclaims, “'There should be Human Akjai! Humans who don't change or die Humans to go on if the Dinso or Toaht unions fail"" (133). Because of his dual-insight into the nature of the resisters, this new colony is formed. Hence, he becomes a worthwhile link between the two and is able to offer his own unique perspective because of this. As the Oankali Akjai explains to Akin, "“You're more Oankali than you think, Akin - and far more Oankali than you look. Yet you're very Human. You skirt as close to the Contradiction as anyone has dared to go. You're as much of them as you can be and as much of us as your ooan dared make you. That leaves you with your own contradiction. It also made you the most likely person to choose for the resisters - quick death or long, slow death"' (233). “'Or life,"” as Akin counters (233).

And when Akin returns to the resister camp after securing the Oankali promise to found a human colony on Mars, though some resisters still rebel against any contact with Akin or the Oankali, many are ecstatic that they will now have a chance at life and procreation and surround him with love, cementing his status as link between peoples $(255,258,268,274)$. Though these humans do not accept the Oankali enough to live in a construct society, they do accept a connection with the Oankali in the chance the Mars colony offers them, indicating their alignment with feminism.

In Imago, Jodahs as child ooloi serves as a link between resister humans and the 
Oankali way, as well as serving as the greater link between humans and the Oankali in both its ooloi and construct status.

Oolois are links in themselves - one interpretation of their name, as mentioned before, means "bridge" (Imago 6). They are the reproductive bridge between both Oankali males and females and between humans and the Oankali. They are integral to the Oankali process. Without the ooloi, there would be no new species, no reproduction, no rescued humans, no Oankali. They embody the Oankali acquisition and study of all life. Up until now, Oankali ooloi did not want to risk developing construct ooloi because of the danger involved - one flawed ooloi could mean destruction for the entire species, as its gene-changing could swerve out of control and change the genetic mappings of all life forms on earth. But when Jodahs accidentally evolves into an ooloi, it becomes not only the future of the species but the ultimate link between humans, the Oankali and constructs. For it represents all three and gives all hope for the future - as ooloi construct, it is part human, part Oankali, all construct. Nikanj, its ooloi parent, sums this up by stating, "II was bred for this trade, but you, you're part of the trade. You can understand both Human and Oankali by looking inside yourself"' (85).

Jodahs is a new sort of ooloi - it is able to manipulate cellular activity the way Oankali ooloi can, but because it is part human it has the added ability to change its shape both consciously and subconsciously to its benefit. And this shape changing, teamed with the fact that it is a child and more likeable and acceptable because of this, goes a long way toward forging bonds with resister humans.

For instance, when it encounters Marina Rivas, a resister human who wants to go 
to Mars, it charms her into forging a temporary relationship with it so that it can study her genes. And she, though she resists the Oankali and particularly the dreaded, cold ooloi whose touch makes her feel drugged (62), allows herself to succumb to its charms. Initially, because it is a child and because it is part human, she tolerantly allows it and its sibling Aaor to touch her, stating that she knows their "kind like to touch everyone" but is not threatened because of their appealing child status (59). And even though she does not want to be genetically changed by adult ooloi so that her daughters will be able to give birth, she states that she wishes Jodahs could change her (63). And because of Jodahs she ultimately agrees to allow an ooloi to change her (65).

Tomás and Jesusa, who become Jodahs' human mates, initially resist Jodahs but succumb to it because of its appealing childhood vulnerability, its ability to heal them, its promise of Mars for their people and its pleasurable arousals in them. Tomás and Jesusa are brother and sister, and they are part of a group of fertile humans who accidentally formed when an ooloi made a mistake with the fertility of one woman more than a hundred years ago and she gave birth to a son after being raped. She mated with her son and began a society of inbred but fertile people who resisted the Oankali way (they believed the Oankali were the devil) and years later her seed has spawned a lost colony of fertility. However, the inbreeding has caused major genetic problems, and most of the people are scarred or deformed, including Jesusa and Tomás. The brother and sister resent having to breed on command, and they take a journey through the forest to gather their thoughts and prepare for their next reproduction. But they meet Jodahs in the forest, and the link it serves between its people and theirs leads to the ultimate saving of the 
fertile humans.

And these humans do need saving - they are not the same as Akjai humans on Mars, for in a hundred years or so the Oankali will take what they need of earth, turn it into a ship and set off into space again, and the fertile humans will be left behind to die in a shell of an earth. It is imperative that these humans accept either the Oankali way or the Mars colony. And because of Jodahs, they do.

Jodahs is appealing to Tomás and Jesusa because it is a child and because it can change its shape to look more human. But this is not enough - Tomás is swayed when Jodahs heals his deformities and physical ailments, but Jesusa needs more than just the sensual passion Jodahs arouses in her (111). When it explains the Mars colony to them, they begin to realize the inevitable and join with Jodahs.

And ultimately, after its healing and other ooloi powers help win the rest of the inbred fertile society over to a connection with the Oankali and the chance to join other resister humans on Mars (211), some of the humans express a desire to remain on earth with the Oankali and constructs if they could have a child construct ooloi like Jodahs, indicating the power of Jodahs as a link between the two societies (198). As Francisco, one of the humans who chooses to remain on earth, states to Jodahs, “'You've done this to me...I would have gone to Mars...I can't even hate you...My god, if there had been people like you around a hundred years ago, I couldn't have become a resister. I think there would be no resisters"' (214). And even remote, detached ooloi Kahguyaht acknowledges, “'We've found resisters who might mate with us.... I don't believe they would even consider us if they hadn't spent these last months living near Jodahs and 
Aaor"" (218).

Hence, by serving as a link between the anti-feminist, hierarchical human race and the cooperative, peaceful, feminist, humanist Oankali society, Nikanj, Akin and Jodahs advance the Oankali society that epitomizes Butler's vision. 


\section{CHILDREN AS EXPLANATION}

Through the treatment and portrayal of children in many science fiction utopia novels, difficult feminist philosophies and structural elements of societies are more easily illustrated. This is evident in all five works: Tepper's The Gate to Women's Country, Charnas's Motherlines, Gearhart's The Wanderground, Ursula K. Le Guin's The Dispossessed and Butler's Xenogenesis series.

The feminist themes and structural elements of Tepper's The Gate to Women's Country are illustrated through the treatment and portrayal of Stavia, Chernon and the Holyland children, products of three vastly different societies.

Stavia is seen as both an adult and a child in the novel, and the portrayal of the child Stavia helps easily and simply to explain Tepper's feminist utopian vision. Women's Country is entirely women-oriented and feminist. Women take their names from their maternal lineage (44); they worship the Great Mother (9); villages are named for women (Susantown, Marthatown, Tabithatown); and the country is run by a Council of mainly medically trained women who heal the women, manage trading and other bureaucratic affairs, and secretly coordinate the selective breeding. Stavia is Councilwoman Morgot's daughter, and as an insider child she helps demonstrate the complicated workings of the society.

Through ten year old Stavia, readers learn that sex is considered a good and healthy activity for all members of society (76), that female children are talked to with the same respect and intelligence that adults are (46) and that paternity is not an important issue for female children. (Selective breeding aside, this highlights the unimportance of 
men to Women's Country.) (114). Readers are also introduced to the poignancy of extinction through Stavia's studies on extinct reindeer. As she uncontrollably weeps over the loss of these animals in her history books, this foreshadows the dilemma Tepper introduces later in the selective breeding of humans (61).

Through Stavia readers are also able to see the strong advocation of balance in this feminist society. All children are forced to select three elements of learning to contribute to society, and they work for their whole lives: they must select an art, a craft and a science (Stavia's are drama, gardening and medicine). The process Stavia goes through as a ten year old child in getting used to the rigors of this lifestyle serve to highlight the benefits of such a structure in a realistic way.

For instance, through Stavia's studies of the play she, as Councilwoman, is later to perform (Iphegenia at Ilium) readers see just how important the performance of and the philosophy behind Iphegenia is. After all, the image of Iphegenia is on the Gate (5). Girls must memorize the lines of the play and tests are given out in school on it (58). And Morgot encourages her daughter to persist with the play, highlighting the careful performances of the Councilwomen themselves:

"When you are grown you may be asked to serve on the Council," she told Stavia. "Half of what we do is performance. Ritual. Observances. If we are seen to be in control, the people are calm and life moves smoothly. Nothing upsets the citizenry more than to believe its administrators are uncertain or faltering. Doing nothing with an appearance of calm may be more important than doing the right thing in a frantic manner. Learn to perform, Stavia. I have." (126)

And readers see how cold the role of Councilwoman must sometimes be in scenes Stavia witnesses between her mother and sister. Morgot and her older daughter Myra 
fight constantly after Myra comes of age and falls for the warrior Barten. Myra comes to embody all the silly girlishness that Women's Country defies, and as Councilwoman Morgot recognizes this and through Stavia's witnessing of these household arguments, readers see the coldness that Councilwomen must sometimes have to act with. This is evident in one scene particularly:

"Barten said..."

Morgot took a deep breath. "Myra. Almost a year ago I told you never to repeat to me Barten's opinions about our ways here in Women's Country. We do not assert the opinions on warriors in Women's Country, particularly opinions on matters about which they know nothing... You have done it twice. Once more and it will go to the Council."

"You wouldn't!" Myra was white with anger. "You wouldn't!"

"Because you are my daughter? It is precisely because you are my daughter that I would. If you cannot accept admonition from me, then it is time others tried with you..." (89)

Likewise, Chernon is a warrior son, clearly not selectively bred and demonstrative of the anti-feminism of the warrior society. Not only does his personal behavior serve to illuminate that - he uses a childhood friendship/romance with young Stavia to try to get her to reveal any Women's Country secrets that she may know (65) - but through his simpler, childish view of the garrison readers can see precisely how awful the male society is and why Tepper's feminist vision is so important.

For instance, through Chernon-as-child we see the reasoning behind the warriors' philosophy. As Chernon explains haughtily to Stavia why he did not lie to a mentally unstable warrior, "“You women don't understand!...he was my superior, my senior, anyhow, and I had to do what was honorable. Warriors don't lie to each other. I tried to tell you women that.... I had to do what Vinsas wanted, even if it was crazy, because that's what we do in the garrison. We obey orders and we don't ask whether the officer is 
crazy or not!"' (75).

And Chernon's attempt to convince Stavia to give him Women's Country books, something considered "womanish" by the warrior philosophy, shows both how much the warriors lack intellectually and also the depths to which these men will sink to try to manipulate the women into giving away any Women's Country secret (78).

Further, when Stavia asks Chernon the name for the elaborate phallic looking statue in the warrior's plaza, a statue highly respected in warrior culture, he blushes and calls it the "reviewing stand," further explaining that it is:

"Just what it looks like...Blooded warriors take their oaths of honor on it. It's a symbol of shared manhood."

"Penis worship?"

"It's symbolic," he said resentfully.

"Yes," she agreed in amazement. "It certainly is." (79)

His frustration at having to sit for fifty days at the bedside of dying warrior Casimur because of this warrior honor (141) leads him into his thoughts on warrior honor, which help explain warrior philosophy the way no other character or scene can:

Chernon believed in honor, as he understood it, as Michael and the others had explained it to him. It was honorable to protect women because warriors needed them to breed sons.... Michael said women weren't strong enough to trust with power or weapons and that if it turned out they had any such thing, it would be perfectly honorable to conquer them and take the power away from them. Women didn't have the right kind of minds to use such things properly, so it would be most honorable to remove the danger from them...

Everyone agreed that it was dishonorable to return through the Gate to Women's Country. Only cowards did it. Cowards and weaklings, though even they could be put to work in the garrison kitchens or doing maintenance of some kind if they confessed their weakness to the Commander....

It was dishonorable to make a Gypsy of a young girl as it unfitted her for breeding, or to make a whore of a boy as it unfitted him for a warrior's life.... It was dishonorable but it wasn't hateful. Going back 
through the gate, that was hateful. (142-3)

As well, the way future warrior leader Michael and his fellow warriors convince young Chernon to try to make Stavia reveal Women's Country secrets by courting her friendship and love not only furthers the storyline but demonstrates just how manipulative, anti-feminist and vindictive these warriors are (64-5).

Through Chernon we also see just how difficult it is for male children to return through the Gate to Women's Country. These boys must endure ceremonious taunts, stonings and other assaults from the garrison as they prepare to walk through the gate. And the boys who choose to return prepare for this attack. As warrior child Chernon absorbs:

Around him everyone was [dressing for the ceremony] except for Habby, and Corrig and the other three. They'd clumped themselves together at the end of the room, waiting for assembly to blow, barefooted, nothing on but their tunics. Habby was smart. Habby must have planned that. A tunic came off fast. Nothing to untie or unbutton. No excuse to knock a man down to take his boots if he was already barefooted. The closer to naked you were when you made the choice, the quicker you could strip. The less excuse for somebody to beat on you while they ripped off your clothes. "Naked you came from your mothers womb, and naked you shall return to Women's Country!" The officers would say that when they got them into the ceremonial room under the wall. "Bloody you came, and bloody you shall go!" some others might say, enforcing the saying with flung stones. (150)

Finally, the portrayal of the Holyland children highlights the philosophy behind the people of the renegade religious fringe society, the Holyland. Although the Holyland people are not central to warrior and Women's Country concerns, they do serve to emphasize just how utopian Women's Country is in light of the wasted condition of the future earth, and they are central to the story in that they endanger Stavia's life when she 
is kidnapped by the group for her breeding capabilities. The Holyland is situated on the far edge of the warrior country, near land not fit for traditional society to live. The group is akin to a religious cult; it is ruled by men, and women are treated as property and taught to believe they are ugly, unclean, unchaste, worthless except for breeding and deserving of nothing better than the subservient life they are forced to lead. In fact, women are considered so inferior to men that when a drought threatened the people thirteen years ago, infant daughters were placed on the mountainside to be devoured by wild animals (203).

Susannah's conversation with eight year old Faith highlights the deep misogyny these men held for females, even children:

The eight year old who came in had obviously been crying and her bodice was soaked and smelly.

"Honey, love. What is it?"

"Elder Jepsom told me I was a slovenly slut."

"You're not. Of course you're not. Why would he say such a thing?"

"Baby threw up all over me. I wouldn't have gone out here where he could see me if I'd known he was there, but I didn't." (201-202)

And polygamy and early forced marriage were common, as thirteen year old Chastity exhibits:

Chastity raised her own yoke and buckets... At thirteen, she was just come to her uncleanliness and not yet to her full growth. No use praying to All Father to let her have a year or two yet before settling her to breed. Some one would be after Chastity before fall, even though it was hard on the very young ones.... If Elder Jepsom didn't make her his sixth, then Elder Demoin, over in the valley, would make her his fourth. (200)

And Chastity's poignant whisper to kidnapped Stavia after the woman asks the baby's name sums up the cold philosophy behind the Holyland people: "'Babies don't 
have names.... That'd be right wasteful"" (255).

Children are also used to explain the feminist (and not so feminist) philosophies behind the differing societies in Charnas's Motherlines. First, the Riding Women's treatment of children in childbirth, in children's movement as a childpack, in their ceremonies and in their reasoning behind wanting children demonstrate some of the more difficult workings of the society and exhibit its feminist philosophy.

For instance, as Alldera prepares to give birth to Sorrel in Stone Dancing Camp, she winces as the familiar pain of the contraction reminds her of the harsh, cold childbearing ritual she experienced in the Holdfast. But instead of the hard pain she braced herself for, she found herself transported by the uplifting singing and joyous celebration of the birth:

The voices of the others joined in a throaty singing. Their song took its rhythm from her breathing and reinforced it. She surged over the pain on their music. The words, which were beyond the tight center of her attention, must have included humor. Rills of laughter erupted and were carried in the song.

She poured with sweat. After the first huge passage of the head she felt the cub's shape, limb and shoulder, work its way out of her. Always before she had been to frightened to feel anything but pain.

...Alldera was astonished at the simplicity of what they did...

People came and put their faces against Alldera's streaming face. Hands massaged her body....

...If she had not been a fem, trained for her life's sake to hide her feelings, she would have wept. (34)

Children and childbirth are beautiful and worthy of such celebration to the Riding Women, serving to illustrate just how utopian this feminist society is.

The Riding Women's treatment of the children in the childpack, as well as the behavior of the childpack itself, also serves to explain the philosophies and inner 
workings of the society. Once weaned, the children of the Riding Women enter an allinclusive pack of "cubs" that resembles that of wild animals or, specifically and tellingly, horses. The all-female children race around the camp, naked, dirty and fierce, speaking their own language, mingling with horses, stealing food and sleeping in a tumble of legs and arms at night. The women are kindly tolerant of the children and do not reprimand them - they exist as an entity completely separate but protected by the Women.

Different tents of Women take turns laying out food for the childpack daily (63). When savage sharu (beasts native to the plains region) threaten the women, the childpack ranges inside the protective perimeter of the scouts (46), but the childpack is otherwise left alone.

Alldera is overwhelmed by the childpack as she makes her first acquaintance with Nenisi:

There came the sound of running steps, very light and swift, and a high babble of voices. Then the tent was full of moving figures, small, naked, and filthy, jostling and pressing close to Alldera as they passed her.

They were a skinny, grimy mob. Their matted hair bounced on their shoulders as they spun away in a swirl of shouts and high-pitched laughter, and they flowed back out of the tent. They brushed past an adult figure in the doorway and were gone. (38-9)

And she learned more about the childpack later, as, "Barvaran and Shayeen talked of a wild dancing game played with the horses, of sleepy sex games, and - in a subdued manner - about harrying the unfit from the pack. Many died in their first pack year" (64). The utter freedom these women give the childpack demonstrates the respect they show to the children. As well, the animalistic behavior of the childpack is perhaps indicative of the "fluid" the women must attain from the horses. 
The Riding Women also take great pride in a child's coming out ceremony, which is held when a child leaves the childpack at menarche and enters the world of the Women. The ritual celebration of the event is best exemplified by Sorrel's coming out, from the procession around the camp (219) to the ritual bath of the child (222) to the "giving of the plains" (224) to the feasting, dancing and other festivities (227). The Riding Women take great pleasure in the celebration of the child and her place in the schematics of her line. As Nenisi sighs in relief at Sorrel's successful coming out, "“A great day, finally, this coming out. Some say that on such a day all elements of the world are placed fresh: living and nonliving, past and future, the spirits of animals and of grass and wind and time passing and even the spirits of stars. Each time we make again the web that is the inner pattern of all things, all things are balanced, the world is made steady"' (224).

Not only does this celebration exhibit the joy the society takes in children, but it gives readers insight into the philosophy behind why children are so important to the Riding Women: their Motherlines. Motherlines are, as Nenisi explains to Alldera, “"Whole strings of blood relations..., women who looked like older and younger versions of each other. They were mothers and daughters, sisters and the daughters of sisters"" (60). And, says old Jesselee, the Motherlines allow the soul of the dead to live on: “"After I live my life and die, I'm still part of my Motherline, with women of my flesh before me and behind me. Death is nothing to get excited about"' (89). Hence, the women value children as a part of the life cycle and the eternal power of the universe and seek to keep that cycle spinning as they produce more children. 
Yet the free fems desire children for a different reason, and this aspect of their treatment of children serves to highlight the differences between the societies.

Free fems desperately want to conceive, but they cannot without men. They pray to their goddess, Moonwoman, to allow them to reproduce without men, but they do not have the genetic alteration that the Riding Women do and are incapable. And yet they, too, hold elaborate conception ceremonies where they inject themselves with earth syrum to attempt to conceive:

The fems came in pairs...and to each pair Daya gave two pots of douche and a syringe to take into one of the wagons. The syringe was to draw the douche and use it in the partner's body. The fems' faces were bright with hope that this time one of the douches would work.

Daya did not believe this would ever happen, but she was pleased to be the dispenser of Fedeka's mixtures on these welcome days of feasting, love, and hops. At least Fedeka knew the plants of the plains so well that the douches were sure to be safe. Free fems no longer poisoned themselves in their efforts to conceive, as in the past. (142)

But the fems do not want children for the life-cycle reasoning the Riding Women want children. Rather, they want them so that they can be used to fight the Holdfaster men, demonstrating the cold, fierce, slave mentality of the free fems. As fem Kobba explains:

"...It may be a long time before I get home, and by then my best strength will be gone. By then there may be only twenty of us going back, not fifty. We'd be weak.

Unless we have some cubs. We can't let our numbers drop or age cut us down. We should go home a conquering army, or why go home at all? If we find the men all dead, that's all right too - we should have young fems there with us to help us break the men's bones and their buildings and trample everything of theirs and bury them in a foot of sea salt, so our cubs will know what their freedom is. If Moonwoman wills it, nothing will be left to show that men ever lived in the world, but our cubs will be there to show that we did." (142) 
And finally, Alldera's appraisal of young Sorrel shows us the harsh reality of the Holdfast. As she looks at her tough child, she realizes, "This child would have never lived to come out of the Holdfast kit pits. The older fems would have judged her too ready to fight. Before she could break some man's teeth for him and bring a flood of femmish blood in reprisal, we would have killed her ourselves. An ordinary idea, in my old life" (223). This exhibits how the anti-feminism of the Holdfast contributed to the fems' own misogyny and hence how easily it could manifest itself in the slave-mentality of the free fems.

In Gearhart's The Wanderground, the experiences and treatment of children help readers understand the complicated feminist philosophies and structure of the Hill Women society.

For the Hill Women, the Remember Rooms are one of the most important parts of the education of their children. As children, all women must enter the Remember Rooms to enable them to understand - through intense memories, tales and invoked feelings the history of the women, why they revolted against the City men's Purges and hunts, and why they (and Gearhart) believe their isolated existence and their bonding with the earth is so necessary.

In the Kochlias, in a windowless room amidst "a dozen other girl-children who were digging out and settling into the places amid giggles and chattering" (138), seven year old Clana participates in one of the most important phases of her Hill Women education: the rememberings.

The rememberings are hundreds of memories of the old life in the City, told 
through mindspeak in story form and taking place over days of intense memories. Some of the tales are horrible memories of rapes, murder and other violence, and guides are required to shield the children from any memory they cannot handle or that they experience too much in their "hardself" and not their deep, semiconscious objective mind (149). Cats assist in the rememberings because they are known to have better memories than the women and can help provide missing or forgotten facts (139). And the rememberings these girls and women experience in the Remember Rooms contribute to their full understanding of their ancestry and why their eco-feminist utopian society is so needed.

As Clana anxiously recounts, "First you had to travel all the way to the Kochlias and then you had to spend the whole morning in ritual singing and dancing and bathing and all the other getting ready. And then you had to hear all about what was going to happen in the remember rooms, how the guides would shield you and then teach you to shield yourself so that you didn't feel all the stories in your hardself...She had looked forward for most of her seven years to this week, to the time when she would learn the rich history of the hill women" (139-40).

Clana is able to handle many of the rememberings, but towards the end of a particularly disturbing segment where she experiences male-female sex (rather than the lesbian or women-earth connections that are all she has known), she is puzzled. And her puzzlement reflects much of Gearhart's gender position: “"How could you let someone enter your body that way and not be a victim?"' (158) Hence, through Clana's rememberings, the history, structure and philosophies of the Hill Women are simplified 
and thus easier for readers to understand.

As well, the Hill Women's treatment of Clana and other children reflects the respect and equality that comprises the society. Girls are called "small women" in this society (136), a title which serves to recognize their importance and contribution to society. They participate in the group mindstretching known as the "gatherstretch" (125), and the women believe that children can always teach them something that needs to be learned. When Clana is traveling to the Kochlias with Alaka and Voki, she helps a wilting fern join with her rhythm and wave its fronds in a more upbeat motion. As Alaka laughingly acknowledges to Voki, “'She can teach us a lot”" (134), symbolizing the childwoman equality of the society.

And through young Jacqua, an older girl just learning to practice her own mindspeak and thought-locking and who constantly recites the Hill Women mantras to increase her confidence in her new mind skills, we see much of the reasoning behind the isolation gender philosophy of the Hill Women: "'It is too simple,' she recited dutifully to herself, 'to condemn them all or to praise all of us. But for the sake of earth and all she holds, that simplicity must be our creed" (2).

And through Jacqua we also realize the non-possessive feminist philosophy of these women in her poignant memory of her learntogether, Ursula:

Lightly in her memory she touched her long-ago warm soft days with Ursula, Ursula who had been her learntogether. She had not forgotten the feeling of needing for life itself Ursula's simple presence. They did not speak their warmness beyond each other to sisters. They had become hidden within it. It began to eat away at their free-standing selves. Hence the saying, "There are no words more obscene than 'I can't live without you.' Count them the deepest affront to the person." Jacqua had not forgotten. In the end she had understood the importance of never feeling 
that way again. (3)

And the significance of the Jacqua section serving as the first chapter of the book is not lost - the simple way children like Jacqua and Clana are used in the novel to explain some of the more complicated psychic and earth-centered philosophies is an effective writing tool.

In Le Guin's complex novel, The Dispossessed, both the Urrasti and Anarresti treatment of children helps to illuminate the highly complicated elements of the opposing societies and their differing views on feminism. Anarres and Urras represent two distinctly separate poles of philosophy. Urras is much like the United States, a society founded on capitalism and consumed by materialism, marketing, competition and money. The society is class-driven with strong gender, racial and financial division lines, and men are clearly superior. Urras has much of the same societal structure of the United States as well; people marry, politicians philander, strip malls abound, money talks. Women are inferior - they stay at home, run the household, supervise the raising of their children, do not attend school, and are so involved in trying to be appealing to men that they actually stitch jewels into their skin and roam topless (men are always clothed) to demonstrate their status as beautiful and charming pets.

Alternately, Anarres is entirely anarchistic, its people having fled Urras to form a life completely devoid of government, structure or rules. The people have rejected any form of traditional Urrasti life - they do not marry, raise their own children or live in their own houses. They reject all forms of possession. If their hand hurts, they do not say "my hand hurts" but rather "the hand hurts me." Children do not consider their parents their 
own but rather refer to them by first name or call them "the mother" or "the father." Monogamous sexual partnering is a rarity and is only accepted if the participants do not "possess" each other and rather happen to live with each other within loose parameters. There is no nuclear family - children are sent to group nurseries and live in dormitories after age two, and parents who keep children at home are accused of possessing. Group think is the norm; individuals do not lecture or preach their own ideas to others as it is considered "egoizing," which is putting the self before the group or reaching for a level that is not consistent with the non-structured, non-possessing Anarresti way. They follow the writings of Odo, a woman born on Urras and imprisoned for expressing her anarchistic view, who spawned the vast drive to Anarres. Their advocation of Odo's philosophies is the only real structure the people have, and by even providing such an infrastructure it is what prevents Anarres from fulfilling a true anarchy. This is a completely feminist society - there are not even gender specific names, as they are assigned from a computer at birth (197-8). Men and women are entirely equal and subjected to the same rigorous work and standards as humans alike.

Anarres and Urras are each other's moons; one cannot exist without the other. Urras is driven by possession, while Anarres is dispossessed. And their treatment of children goes a long way in explaining the complicated elements of these societies and highlighting their differences, especially in terms of feminism.

Much of the Anarresti way is exhibited through the childhood of Shevek, from his education to his behavior. On Anarres, children leave their homes and live in nurseries and dormitories from the age of two $(26,102)$. The children belong to the entire culture 
this way, and no one parent is responsible for their upbringing. Babies in nurseries are "cooped up in large, padded pen-cots in pairs or trios," allowing children to understand the importance of the group over the individual from the start (26). Gender is a nonissue, even at birth. When Shevek's wife later gives birth to their child, they do not immediately look for the gender of the child as American society does; rather, almost as an afterthought, Shevek's wife asks sleepily as they settle down to nap, "'What is it?"” (244). Children call their parents by their first names (32). They are treated with respect, and sexuality and complicated intellectual ideas are not barred from them. Palat, the father, explains to eight year old Shevek that he wishes to "copulate with a woman named Pipar. He had explained all this to his son. Shevek trusted him, and he deserved trust" (31). As well, Palat explains the slide rule to Shevek and Shevek explains light physics to his father - they both learn from each other (32).

When Shevek finally meets his mother Rulag many years later at a hospital in Abbenay, she does not lay any claim to him. She introduces herself as "the mother" (120), and then states as she leaves, “'We aren't except biologically, mother and son, of course.... You don't remember me, and the baby I remember isn't this man of twenty. All that time is past, irrelevant. But we are brother and sister, here and now. Which is what really matters, isn't it?'”(124). This statement captures the dispossessed philosophy of Anarres, especially evident in mother-son relations.

Anarres children are also able to have sex and to dabble in both genders, and this notion is accepted by society. As Shevek muses, "Like all children of Anarres he had had sexual experience freely with both boys and girls" (51). 
When Anarresti put the self over the interest of the group, they are considered to be "egoizing," and their punishment is to be forced to sleep alone or leave the city or learning group. We see this and other Anarres ways in Shevek's education experiences. As an infant, Shevek both exhibits the dispossession of Anarres and his own individuality. A "knobby baby" in the community nursery, he howls at the unfairness of being pushed into the shade by a fatter infant:

"Mine!" he said in a high, ringing voice. "Mine sun!"

"It is not yours," the one-eyed woman said with the mildness of utter certainty. "Nothing is yours. It is to use. It is to share. If you will not share it, you cannot use it." (26)

Shevek at eight shows us the style and philosophy behind the learning centers as well. The learning centers advocate balanced education - not only do they learn academics but art, manual labor skills and group think as well. The centers are organized on "student demand, or on the teacher's initiative" (126); there is no bureaucratic school board to assign or develop classes for children, and learning is optional, though everyone participates. There are no tests or grades (127), and the children are indoctrinated through their studies of the Life of Odo (34), through their encouragement to hate the Urrasti system (43), and through their treatment of egoizing. When Shevek explains a physics concept that is important to him to his learning center Speaking-and-Listening group, teaching the other children rather than "sharing" it, he is reprimanded and ordered out of the group. As the encounter between Shevek and the group director displays:

"Who told you this idea?"

"Nobody. I sort of saw it. I think I see how the rock actually does - " "That's enough.... Speech is sharing - a cooperative art. You're not sharing, merely egoizing...This kind of thing is really directly contrary to what we're after in a Speaking-and-Listening group. Speech is a two-way 
function. Shevek isn't ready to understand that yet, as most of you are, and so his presence is disruptive to the group. You feel that yourself, don't you Shevek? I'd suggest that you find another group working on your level." (35-6)

Later, as Bedap passionately exclaims to Shevek, encapsulating the power of education on society, “'Nobody's born an Odonian any more than he's born civilized! But we've forgotten that. We don't educate for freedom. Education, the most important activity of the social organism, has become rigid, moralistic, authoritarianism. Kids learn to parrot Odo's words as if they were laws - the ultimate blasphemy!"'(168). These words help to exhibit the notion of education as propaganda and influential of any society's gender and other relations.

On Urras, however, children are tucked away like some dirty dark secret, indicative of the many hidden faces of Urras culture. Urrasti are not forthcoming about their rapacious attitude toward competition or rules, and only through Shevek's coincidental glimpses is he able to learn anything real about Urras society. However, Shevek's experiences with the Oiie children serve as the most concrete clarification of the Urrasti way.

Shevek has not yet seen any children on Urras when he is invited to Oiie's house for the weekend. There, he encounters Oiie's two young boys, and the household's treatment of the children is a metaphor for the possessive, regulated society Shevek is a guest in.

The boys are never introduced - they are only referred to as the nine-year-old and the seven-year-old until their names mysteriously crop in halfway through dinner (148). They are only present at the dinner table because their nursemaid was not available, 
indicative of the non-importance of the children to the culture (146). They are careful, controlled entities, completely representative of Urras, "very clean, sedate children, speaking when spoken to, dressed in blue velvet coats and breeches.... The nine-year-old was severe with the seven-year-old, muttering at him not to stare, pinching him savagely when he disobeyed" (146). They are bewildered when Shevek does not exhibit traditional Urrasti manners by saying "please" or "thank you," as is Shevek confused at their bewilderment: "“Were they a gift? We say thank you only for gifts, in my country"” (147). In short, even as children they are perfect replicas of Urrasti society and they are vastly different from any Anarresti view of children offered so far in the novel.

But as children they are still innocent, and their almost immediate liking of Shevek and Shevek's tales of the Anarresti way serves to illuminate the power of education on society's thinking. When Shevek begins to mention certain aspects of life on Anarres, the boys immediately grill him for more information about the planet. As Shevek realized:

It was the first time Shevek had been asked, on Urras, to describe Anarres. The children asked the questions, but the parents listened with interest. Shevek kept out of the ethical mode with some scrupulousness; he was not there to propagandize his host's children. He simply told them what the dust was life, what Abbenay looked like, what kind of clothes one wore, what people did when they wanted new clothes, what children did in school. This last became propaganda, despite his intentions. Ini and Aevi were entranced by his description of a curriculum that included farming, carpentry, sewage reclamation, printing, plumbing, roadmending, playwriting, and all the other occupations of the adult community, and by his admission that nobody was ever punished for anything. (148)

While this little speech served as the catalyst for the adult's inquisitiveness and ultimate resistance of the Anarresti culture, the Oiie children accepted Shevek's lifestyle 
with openness and intrigue. However, Oiie did not know quite how to handle his children's acceptance of Shevek's lifestyle: "By the second visit his two sons had decided that Shevek was an old friend, and their confidence in Shevek's response obviously puzzled their father. It made him uneasy; he could not really approve of it; but he could not say it was unjustified.... They admired him, and the younger, Ini, came to love him passionately.... but there was more to it than that. He represented something to the child that Ini could not describe" (194-5).

If the Oiie children, in all their openness as children, had been raised in Anarres, they would have been equally as indicative of the Anarresti culture. This aspect alone demonstrates the novel's ultimate point about the power of education as the predominant influential tool for people's behavior and, hence, their gender relations.

And the portrayal of the Urrasti school system is also emblematic of the culture, reflecting the serious gender division and competitiveness of the society. Shevek teaches at the university, which women do not attend (129). The remaining half of the society is further divided, as only aristocratic male children attend (128). Unlike the Anarresti system, children learn impractical academics and crave the testing and grading process, as it serves to demonstrate which students are "better" and "smarter" than the others. Shevek tries to change the system by not giving these tests and giving all students passing grades, but to his surprise the students actually demand them. As the students objected: "How could the diligent students be distinguished from the dull ones? What was the good in working hard? If no competitive distinctions were to be made, one might as well do nothing" (128). 
Hence, the extreme group mentality and gender freeness of Anarres that are portrayed through the treatment of children and the education process (as experienced and evidenced by Shevek) exhibit Le Guin's feminist vision, while the anti-feminist competitive, individualistic, possessive, patriarchal Urrasti dystopia is exhibited best through the Oiie children and through Shevek's teaching experiences.

The treatment of children in Butler's Xenogenesis series also helps to explain the feminist and structural elements of the Oankali society and the anti-feminist and violent mentalities of the human resisters. In both Adulthood Rites and Imago, books two and three of the series, the humans' treatment of Akin, a male human-Oankali construct child, and Jodahs, a child construct ooloi, identifies the polar opposites of the societies in terms of their acceptance or non-acceptance of the Oankali way (which are actually metaphors for their feminist or anti-feminist philosophies).

The treatment of male construct child Akin by the humans in Adulthood Rites serves as an excellent indicator of the ideologies behind the differing peoples. Most humans adopt one of two attitudes toward their merging with the Oankali - they accept it for their own survival through procreation, and hence they accept the intelligent, peaceful, feminist and humanist Oankali way, or they reject it adamantly, refusing to merge with the Oankali at any cost and setting up their own societies far from the Oankali settlements where they carry on a violent, caveman-like existence reminiscent, they believe, of the prewar days.

Akin, as discussed before, is kidnapped by the resister humans when he is an infant and comes to serve as the link between the two societies, as many of the resisters 
come to like Akin and ultimately forge a connection with the Oankali through the Mars colony. And Butler clearly advocates the Oankali way when Lilith explains the difference concept to the infant Akin. As she states, "'Human beings fear difference...Oankali crave difference. Humans persecute their different ones,...Oankali seek difference and collect it.... You'll probably find both tendencies surfacing in your own behavior.... When you feel a conflict, try to go the Oankali way. Embrace difference"” (80).

Those humans who do like Akin and treat him as a person are the most Oankalilike (to Butler, hence, the most feminist), while those who are repulsed by the child are repulsed by what he represents and are the most human, strongly exhibiting the antifeminist Human Contradiction.

Butler subtly implies that female humans are the most Oankali-like, and their treatment of Akin exhibits this. For instance, even though Akin is known to be a construct, the women of one of the trading villages he is taken to when he is first kidnapped immediately disregard the fact that he is a construct and they feed him and bathe him as if he were one of their own children (94). And when he is taken to Phoenix, Tate, a resister woman, immediately grants him the respect of an equal - regardless of his breed. She asks him his name, is not shocked when he can speak, and proceeds to have an intelligent conversation with him, indicative of their entire relationship from then on (101-2). Later, she actually lets Akin taste her (absorb her cellular structure through his sensory tongue), for even though she does not like it she knows it is important to him (117). And Yori, Phoenix's female doctor, impulsively hugs Akin moments after meeting him - for despite the fact that he is part Oankali, he behaves entirely human 
when he fibs about an attacker and saves the attacker's life in the process (108).

Resister males are the least Oankali-like. They are entirely hierarchical and women are possessions to them like all other precious "items" are - children, metal tools, glass (71). They are violent, and they resist the Oankali way in part because they resent being "taken like a woman." The fact that they steal Akin exhibits their violent maleoriented non-Oankali behavior (59). But it is also their revolted treatment of Akin en route to trading him that cements the division between the peoples. For instance, one of his kidnappers holds him "as disgustedly as he had once seen another man hold a snake. Was he as alien as a snake to these people?" (67). Later, when the men are drunk, three of the men try to feed Akin a deadly mixture of poisoned mashed beans until he vomits all over them and they stagger away (72). And when one of the men is in agony, coughing up blood and dying of a stomach ulcer, the other kidnappers immediately resist Akin's suggestion that they take him to an ooloi, even though that is clearly the only thing that will save his life (79).

These men clearly illustrate the non-Oankali way, representative of the behavior of most human males. But not all males exhibit such behavior, allowing a few of them, as evidenced by their acceptance of Akin, to embrace the Oankali way. Tino is a good example of this. A resister male who fled the hopeless resister society to find out what the other side was like, he comes to prove his Oankali-oriented attitude through his encounters with Akin. For instance, although at first Tino is bewildered by the baby's ability to talk, he quickly learns to respond to the child and carries on a conversation with him (24). And he comes to forge a strong bond with Akin in spite of the fact that he had 
been taught to resist anything connected with the Oankali. He comes to call Akin "son" (55), and he spends long days with Akin alone, content to explore the woods together (53-

4). And his complete acceptance of Akin is the most symbolic example:

Tino had been told why Akin put things in his mouth. He did not understand, but he never tried to keep things out of Akin's mouth the way other visitors did. He could accept without understanding. Once he had seen that a strange thing did no harm, he no longer feared it. He said Akin's tongue looked like a big gray slug but somehow this did not seem to bother him. He allowed himself to be probed and studied when he carried Akin about. Lilith worried that he was concealing disgust or resentment, but he could not have concealed such strong emotions even from Akin. (54)

This acceptance of Akin and the other construct children (as well as the Oankali society) is echoed by the other human males who choose to remain with the Oankali as well. Though their numbers are few - there are only five men in the construct village when Tino comes to them (33) - they do exist, and their behavior indicates that Butler does not believe they are lost, even if she implies that human females are inherently more like the Oankali.

Finally, in Imago, the treatment of Jodahs by the male and female humans also serves as an indicator for their eventual acceptance of the Oankali. At the start of the novel, Jodahs encounters some resister humans who journey to the camp so they can be sent to the Mars colony. The female is immediately interested in Jodahs and even reaches out to touch it as they turn to leave (Imago 12), again exhibiting women’s inherent acceptance. As Jodahs acknowledges, "Humans females did tend to like me as long as I kept my few body tentacles covered by clothing and my few head tentacles hidden in my hair (7). However, though Jodahs is able to adapt its form to look human-like and thus 
pleasing to outsider humans, when a resister male learns that Jodahs is not a human female at all but a child ooloi, he is instantly closed to it and their connection is broken (76-77) - indicating the rejection of difference inherent in most human males.

Thus, the treatment of construct children Akin and Jodahs help readers discern the feminist and anti-feminist traits Butler subtly implies in the humans. 


\section{CONCLUSION}

Feminist blueprints for the future can sometimes be, as Marleen Barr says, quite dangerous (Lost 52). They introduce areas of feminist and humanist issues that society is often not quite ready to deal with yet. They strike out into uncharted territory, and they sometimes disturb the reader by illustrating something distressing about our future, and our society, in a way no other fiction genre can. They advocate societal change.

But what can be particularly disturbing about the books discussed in this thesis is that, with the exception of Le Guin's The Dispossessed, every one of them offers biological change as a means for evoking a feminist future. In Tepper's The Gate to Women's Country, only through selective breeding can society create the ideal feminist future. In Charnas's Motherlines, women self-reproduce with the help of horses to create an all-woman cloned society. In Gearhart's The Wanderground, women achieve parthenogenesis through union with the earth. In Butler's Xenogenesis series, humans mate with the Oankali to create a new breed of feminist alien-human construct children. Only The Dispossessed offers a feminist future based on anarchistic principles fostered through separatist education and without biological change (though they must travel to the moon to achieve this society).

The nature vs. nurture debate, swinging the social pendulum between one and the other, has transformed much of modern attitude about formerly taboo subjects. The alcoholic or homosexual gene is said to be responsible for broader social acceptance of these behaviors. Criminals are using the abused-child defense to absolve them from full responsibility for their crimes. And the cloning of the sheep Dolly underscores human 
control over the genome (Fukuyama). As Doyne Dawson maintains in his philosophical treatment on war:

Clearly the debate between nature and nurture, perhaps the longest-running controversy in the history of science, is still vigorous. Its two main battlegrounds have always been warfare and gender, two closely related subjects that raise so many interesting questions about human nature that to take a scientific position on these issues is usually thought to imply a political agenda: the authors of the Seville Statement take it for granted that to say warfare is in human nature is "to justify violence and war," while to call these products of human nurture is to suggest they can and should be easily controlled. The issue is complicated by the fact that in the twentieth century it has tended to become a war of the faculties, with biologists, including many biological anthropologists, on the side of nature and cultural and social anthropologists flocking to the banners of nurture. Much of it is a dismal story of inconclusive and repetitious rounds between passionately held half-truths.

This nature-nurture debate applies to feminism as well. As critic Hoda Zaki states:

Two interpretations have emerged from the feminist debate on human nature: the essentialist and the materialist. The former argues for the primacy of female anatomy as the central and determining factor in shaping the female unconscious and conscious mind. The female body, in other words, is the locus of difference as well as the basis for unity and social change. The materialist interpretation, to the contrary, prefers to explain the oppression of women by focussing on the social and historical construction of gender and self (cf. Jones). ("Utopia, Dystopia" 240).

In his article, "Reconsiderations of the Separatist Paradigm in Recent Feminist

Science Fiction," Peter Fitting cites Gearhart's The Wanderground as the best example of the essentialist pole, in which men are viewed as violent by nature and that only through biological change can we achieve a feminist future (33). As well, he states, Tepper's The Gate to Women's Country "shifts the utopian focus away from the contours of the alternative community to the mechanism for achieving the better society -- one based on changing 'human nature' and the male predisposition to violence" (39). 
In analyzing Charnas's Motherlines, Marleen Barr asserts that readers should be less shocked by the biological necessity of women who must copulate with their horses and more horrified by the fact that women in the Holdfast were raped and forced to eat $\operatorname{dirt}$ (Women and Utopia 58).

And Butler's Xenogenesis series is permeated with some of the strongest arguments for biological change. According to Cathy Peppers, the very word Xenogenesis means "the production of offspring different from either of its parents'; this is reproduction with a difference, the (re)production of difference" (47). Accedes Hoda Zaki, "The force by which humans are wedded to their biologically-determined nature and their inability to transcend it she makes clear in her 'Xenogenesis' series.... Butler's unmediated connections between biology and behavior have an implicit corollary: that abandoning the human body is a necessary prerequisite for real human alteration" ("Utopia, Dystopia" 242). And, says Donna Haraway in her primate exploration, Primate Visions, "Her fiction, especially in Xenogenesis, is about the monstrous fear and hope that the child will not, after all, be like the parent.... Some other order of difference must be possible in Xenogenesis that could never be born in the Oedipal family narrative (3789). Further, says Eric White, "The trilogy can in fact be said to intervene in and reverse a tradition of paranoiac responses to evolution in which Nature in effect persecutes Culture.... And this is so much that, in Xenogenesis, the Thing has become the hero of the tale" (402). And finally, asserts Peppers, "That Butler chose to title the ultimate volume of her trilogy Imago - which means the 'perfect stage' of an animal at the end of its evolution - suggests that she is indeed telling a story of evolution in which the 'most 
fit' will survive" (56).

But a biological change in humanity is not the only viable blueprint for a feminist society in these novels. The striking portrayal of Le Guin's anarchistic society Anarres offers a strong alternative to the biological remedies Tepper, Charnas, Gearhart and Butler espouse. Her system is, of course, founded on the Odonian philosophy of total anarchy, and, as Philip Smith states, "Le Guin's thesis is that the anarchism on Anarres, despite its imperfections, represents the best hope for human political, moral, and evolutionary progress (79). In referencing an interview that Jonathan Ward had with Le Guin, Smith infers that The Dispossessed does not have any need for biological alteration when the human spirit, in which Le Guin has utmost faith, can have the will to achieve her anarchistic ideal of a utopian society. As he explains, "An optimistic view of human nature characterizes anarchist theory; basically it sees humans as capable of achieving the good socially and morally only if they arrange to live cooperatively, uncorrupted by the authority of government. Le Guin shares this view and incorporates it as an important factor in the structure of ideas, characterization, metaphor and theme in The Dispossessed" (78).

Lucy Freibert explores the anarchistic teachings of Odo in The Dispossessed as the basis for Le Guin's non-biologically altered utopia. As she states, "The utopian community in Le Guin's novel originates in social upheaval and develops in modest, though scientifically advanced, circumstances" (72). Certainly, Anarres is slow in developing - society may have the will to change, but it is through the vast purely anarchistic educational system and language on Anarres that Le Guin's ultimate utopia is 
achieved. As Freibert argues:

The Odonians' achievement of an organicism, given their roots in anarchy, is as much a miracle as parthenogenesis in Herland. Leaving behind the hierarchical, codified laws of men and following Odo's organicist principles, each person concentrated on developing his or her own life to the fullest, simultaneously combining the complexity, vitality, and freedom of invention and initiative essential to Odonian ideals.

The antithetical ideals of freedom and solidarity become the touchstones of the land. Odo's principles of revolution and suffering integrate the two. Odo teaches that each person contains the spirit of revolution within.

....Because of the integration of the ideals of freedom and solidarity, no formal government is needed in Anarres to control the country's systems. (72-3).

In short, the words of Bedap in The Dispossessed encapsulate Le Guin's social conditioning approach to her feminist vision: "Nobody's born an Odonian any more than he's born civilized!'" (168).

But the biological alternatives proffered in The Gate to Women's Country, Motherlines, The Wanderground and the Xenogenesis series do not indicate the authors' total advocation of nature over nurture. Indeed, each work does embrace some form of non-biological argument in the center conflict and they all acknowledge that biology alone cannot achieve an ideal feminist utopia. For instance, in the Xenogenesis series, much of the conflict is consumed by the ethical question of abandoning the human race to merge with the aliens. At the culmination of book two, Adulthood Rites, the humans are given the opportunity to begin a new world on Mars free from Oankali intervention, indicating Butler's acknowledgment of the opportunity for human evolution without biological alteration. And in The Gate to Women's Country, Tepper gives the dissent a strong voice in main character Stavia, who emotionally objects to the forced extinction of 
the violent males.

And although the women in The Wanderground happily exist apart from all men, bred themselves as part of the earth and hence in perfect unity with nature, they still rely on an intricate educational system (from "Remember Rooms" to "learntogethers") to impress upon each member of society the necessity of preserving their lifestyle. And their embracement and advocation of the bond between woman and woman, and woman and earth, serves, as Lucy Freibert explains, as "an expansive environment, free of fear, in which they can develop previously undreamed-of powers. This freedom from fear gives the women courage to trust the lonth (the subconscious), allowing it to do things that the conscious self could never effect. They learn mental telepathy and the power of mental healing. They learn to move objects through space, to produce glow lobes (free-floating lights), to levitate and fly through the air (wind-riding), and to swim long distances under water, even through underground caverns" (80). In short, these women cannot intrinsically trust this "lonth" without the sort of social conditioning that Gearhart recognized as necessary to their feminist experience.

Likewise, Charnas's all-female societies in Motherlines do not rely entirely on biological change to affect the perfect feminist utopia. As Margaret Miller maintains, the very fact that Charnas designed these women with a wide array of "negative" characteristics, including violence, indicates her view that women are not born perfect. It is up to the social institution of "female bonding," expressed primarily in the novel through unfettered sexuality, to temper the women's violence and to create the sort of feminism Charnas advocates. As Miller states: 
Charnas, reflecting contemporary feminist distrust of limiting female nature to a set of traditional attributes, accords her individual characters a full range of human characteristics, from violence and competitive individualism to nurturance and co-operation. However, personal traits destructive to the group are channeled and disciplined by a social system which stresses kinship, both biological and emotional, of which motherhood is only one form. Hence, sexuality, totally unnecessary for reproduction, is valued as a mode of female bonding, a reinforcement on an emotional level of a cultural norm of co-operation. (196)

Feminists, as do other theorists, embrace both sides of the nature-nurture polemic, and it is unlikely that the debate will be reconciled on any level anytime soon. As Wray Herbert, in "The Politics of Biology," reiterates: "If there's a refrain among geneticists working today, it's this: The harder we work to demonstrate the power of heredity, the harder it is to escape the potency of experience."

The apparent advocation of biological change as the preferred route to utopian feminism cannot be read as absolute, nor can the strength of education and other pushes for social reform be ignored. Until society achieves that "gender equality" that is just now beginning to take root as we approach the next century, we will need an outlet as strong and as vital as science fiction utopian literature to pave the way for feminist strides and feminist futures.

Of course, as Donna Haraway says, "It has become difficult to name one's feminism by a single adjective - or even to insist in every circumstance upon the noun...There is nothing about being "female" that naturally binds women" ( But as long as society must confront issues of wage discrimination, abortion restrictions and sexual harassment, as long as there are still prejudicial notions about a woman "daring" to be president, then we will still need a strong outlet for feminism. 
"Feminist science fiction can inspire real world change," states Barr. "The girl who makes sand castles - constructs foundations for new feminist fairy tales that might come true - is not building castles in the air" (Lost 8-9). Thanks to feminist science fiction utopianism, the pathway into the Millennium is a little less dense, a little less defined, and a lot more open to all kinds of feminism. 


\section{WORKS CITED}

\section{Primary Sources}

Butler, Octavia. Dawn: Book One of the Xenogenesis Series. New York: Warner Books, 1987.

- -. Adulthood Rites: Book Two of the Xenogenesis Series. New York: Warner Books, 1988.

- -. Imago: Book Three of the Xenogenesis Series. New York: Warner Books, 1989.

Charnas, Suzy McKee. Motherlines. New York: Berkley Publishing Corp., 1978.

Gearhart, Sally Miller. The Wanderground. Boston: Alyson Publications, Inc., 1979.

Le Guin, Ursula K. The Dispossessed. New York: HarperPrism, 1974.

Tepper, Sheri S. The Gate to Women's Country. New York: Bantam Books, 1988.

\section{Secondary Sources}

Armitt, Lucie. Where No Man Has Gone Before: Women and Science Fiction. London: Routledge, 1991.

Barr, Marleen. "Feminist Fabulation; or, Playing with Patriarchy vs. the Masculinization of Metafiction." Women's Studies 14:2 (1987): 187-191.

-.-, Lost in Space: Probing Feminist Science Fiction and Beyond. Chapel Hill: University of North Carolina Press, 1993.

- - - "Utopia at the End of A Male Chauvinist Dystopian World: Suzy McKee Charnas's Feminist Science Fiction." Women and Utopia: Critical Interpretations. Ed. Marleen Barr and Nicholas D. Smith. Lanham: University Press of America, 1983. 43-66.

Burke, Kenneth. The Philosophy of Literary Form: Studies in Symbolic Action. Berkeley: University of California Press, 1973.

Dawson, Doyne. "The Origins of War: Biological and Anthropological Theories." History and Theory. 35:1 (1996): 1-28. WilsonSelect. Online. First Search. 8 May 1999.

Day, Phyllis J. "Earthmother/Witchmother: Feminism and Ecology Renewed." 
Extrapolation 23:1 (1982): 12-21.

DiSilvestro, Roger L. "Books to Remember." BioScience Oct. 1997: 609-13.

WilsonSelect. Online. First Search. 13 May 1999.

"Feminist Criticism." A Glossary of Literary Terms. 5th ed. 1988.

Feuer, Lois. "The Calculus of Love and Nightmare: The Handmaid's Tale and the Dystopian Tradition." Critique 38 (Winter 1997): 83-95.

Fitting, Peter. "For Men Only: A Guide to Reading Single-Sex Worlds." Women's Studies 14:2 (1987): 101-117.

- - , "Reconsiderations of the Separatist Paradigm in Recent Feiminist Science Fiction." Science-Fiction Studies 19 (1992): 32-48.

Freibert, Lucy M. "World Views in Utopian Novels by Women." Women and Utopia: Critical Interpretations. Ed. Marleen Barr and Nicholas D. Smith. Lanham: University Press of America, 1983. 67-84.

Fukuyama, Francis. "Is it all in the Genes?" Commentary Sept. 1997: 30-5.

Haraway, Donna J. Primate Visions: Gender, Race, and Nature in the World of Modern Science. New York: Routledge, 1989.

- --, Simian, Cyborgs, and Women: The Reinvention of Nature. New York: Routledge, 1991.

Herbert, Wray. "Politics of Biology." U.S. News and World Report 21 Apr. 1997. WilsonSelect. Online. First Search. 8 May 1999.

Mellor, Anne K. "On Feminist Utopias." Women's Studies 9 (1982): 241-62.

Miller, Margaret. "The Ideal Woman in Two Feminist Science Fiction Utopias." Science-Fiction Studies 10:2 (1983): 191-198.

Murphy, Patrick D. "Feminism Faces the Fantastic." Women's Studies 14:2 (1987): 81-90.

Neustadter, Roger. "An End to 'Childhood Amnesia': The Utopian Ideal of Childhood in Critical Theory." Mid-American Review of Sociology 16:2 (1992): 71-80.

Pearson, Carol. "Coming Home: Four Feminist Utopias and Patriarchal Experience." Future Females: A Critical Anthology. Ed. Marleen S. Barr. Bowling Green: Bowling Green State University Popular Press, 1981. 63-70. 
Peppers, Cathy. "Dialogic Origins and Alien Identities in Butler's Xenogenesis." Science-Fiction Studies 22:1 (1995): 47-62.

Pfaelzer, Jean. "The Changing of the Avant Garde: The Feminist Utopia." ScienceFiction Studies 15:3 (1988): 284-94.

Reed, Lawrence W. "How a Food Safety Myth Became a Legend." Consumers' Research Magazine Feb. 1995: 23-25.

Roemer, Kenneth M., ed. America as Utopia. New York: Burt Franklin \& Co., 1981.

Russ, Joanna. "Recent Feminist Utopias." Future Females: A Critical Anthology. Ed. Marleen S. Barr. Bowling Green: Bowling Green State University Popular Press, 71-85.

Sargent, Lyman Tower, comp. and ed. British and American Utopian Literature 15161985: An Annotated Bibliography. New York: Garland Publishing, Inc, 1988.

Sargisson, Lucy. Contemporary Feminist Utopianism. London: Routledge, 1996.

Scholes, Robert, and Eric S. Rabkin. Science Fiction: History, Science, Vision. New York: Oxford UP, 1977.

Smith II, Philip E. "Unbuilding Walls: Human Nature and the Nature of Evolutionary and Political Theory in The Dispossessed." Ursula K. Le Guin. Ed. Joseph D. Olander and Martin Harry Greenberg. New York: Taplinger Publishing Company, 1979. 77-96.

Sobchack, Vivian. "Child/Alien/Father: Patriarchal Crisis and Generic Exchange." Camera Obscura: A Journal of Feminism, Culture and Media Studies 15 (Fall 1986): 7-34.

"Stowe, Harriet Beecher." Encarta Concise. 2 Dec. $1998<$ http://encarta.msn.com /index/conciseindex/45/045c6000.htm>.

White, Eric. "The Erotics of Becoming: Xenogenesis and The Thing." Science-Fiction Studies 20:3 (1993): 394-408.

Zaki, Hoda M. "Utopia and Ideology in Daughters of a Coral Dawn and Contemporary Feminist Utopias." Women's Studies 14:2 (1987): 119-133.

- - - " "Utopia, Dystopia, and Ideology in the Science Fiction of Octavia Butler." Science Fiction Studies 17:2 (1990): 239-51. 